\title{
28. SEDIMENT GEOCHEMISTRY, CLAY MINERALOGY, AND DIAGENESIS: A SYNTHESIS OF DATA FROM LEG 131, NANKAI TROUGH ${ }^{1}$
}

\author{
Michael B. Underwood, ${ }^{2}$ Kevin Pickering, ${ }^{3}$ Joris M. Gieskes ${ }^{4}$ Miriam Kastner, ${ }^{4}$ and Robert $\mathrm{Orr}^{2}$
}

\begin{abstract}
This paper presents a synthesis of data from X-ray diffraction analyses of clay minerals and X-ray fluorescence analyses of bulk mudstones from Ocean Drilling Program Site 808. The samples come from three closely spaced holes drilled through the toe of the Nankai accretionary prism offshore Shikoku, Japan. Detrital assemblages of clay minerals are unusually uniform throughout the Nankai trench-wedge facies. Illite is the most abundant detrital clay mineral, followed by chlorite, smectite, and traces of kaolinite. Relative percentages of smectite increase within the upper subunit of the Shikoku Basin stratigraphy. This subunit contains abundant layers of volcanic ash, and the corresponding change in clay mineralogy probably was caused by synvolcanic weathering in source areas during the Pliocene, together with in-situ alteration of disseminated glass shards within the Shikoku Basin.

At a depth of $\sim 555 \mathrm{mbsf}$, the detrital and/or authigenic smectite component begins its transformation to illite/smectite mixed-layer clay. With increasing depth below this horizon there is a monotonic increase in illite interlayers. The onset of illitization occurs at an estimated temperature of $\sim 65^{\circ} \mathrm{C}$. Ordered $(R=1)$ illite/smectite interlayering first appears at depths of $\sim 1220 \mathrm{mbsf}(<2-\mu \mathrm{m}$ size fraction) and $\sim 1100 \mathrm{mbsf}(<0.2-\mu \mathrm{m}$ size fraction). The depth interval of the smectite-to-illite transformation coincides with a reduction in pore-water chlorinity; however, the absolute abundance of smectite appears to be insufficient to account for the changes in aqueous chemistry via in-situ dehydration reactions. Instead, significant volumes of diluted pore water probably were transported to Site 808 , either from sources located deeper in the accretionary prism (where bulk mudstone porosities are lower) or from lateral sources where mudstones originally deposited in the Shikoku Basin may contain higher percentages of smectite. Significantly, we did not detect any anomalies in clay mineralogy or clay-mineral diagenesis within or near the décollement zone (945-964 mbsf).

X-ray fluorescence analyses show that hemipelagic muds and mudstones at Site 808 are chemically uniform throughout most of the section. There are no geochemical perturbations, for example, within the décollement zone. Data from interbeds of volcanic ash demonstrate that the chemical effects of mud/ash dissemination and/or in-situ alteration of pyroclastic material are limited. In addition, ash layers are chemically heterogeneous within Unit III and Subunit IVa, which indicates that tephra was transported from a variety of andesitic to rhyolitic sources on the Japanese Islands during the Pliocene. In contrast, Miocene rocks of Unit V display a clear chemical divergence (little mixing) between rhyolitic tuffs and interbeds of multicolored mudstone.

The most significant geochemical anomaly at Site 808 occurs well below the décollement zone between 1087 and 1111 mbsf. Variegated mudstones in this interval contain unusually high ratios of $\mathrm{MgO} / \mathrm{Al}_{2} \mathrm{O}_{3}, \mathrm{Fe}_{\text {total }} / \mathrm{Al}_{2} \mathrm{O}_{3}, \mathrm{MnO} / \mathrm{Al}_{2} \mathrm{O}_{3}$, and $\mathrm{CaO} / \mathrm{Al}_{2} \mathrm{O}_{3}$, together with high concentrations of $\mathrm{Ba}, \mathrm{Y}, \mathrm{Sr}, \mathrm{La}$, and $\mathrm{Ce}$. We attribute this anomaly to hydrothermal alteration and/or precipitation of Ca-carbonate, siderite, barite, and related minerals, but we do not know when the event occurred. Fluid migration may have taken place during late Miocene time early in the depositional history of Shikoku Basin (i.e., above newly formed oceanic lithosphere) or during the Holocene as fluids advected through the Nankai accretionary prism.
\end{abstract}

\section{INTRODUCTION}

Site 808 of the Ocean Drilling Program (ODP) is located near the base of the Nankai accretionary prism of southwest Japan (Fig. 1), close to where the extinct backarc spreading ridge of the Shikoku Basin intersects the deformation front (Le Pichon et al., 1987; Taira et al., 1992). Cores recovered from Holes $808 \mathrm{~A}, 808 \mathrm{~B}$, and $808 \mathrm{C}$ have been grouped into five major sedimentary facies units, as well as several subunits, which range from Miocene to Quaternary in age (Fig. 2). The uppermost facies comprises a thin carapace of trenchslope sediments that accumulated above accreted trench and abyssalplain deposits. The chaotic style of deformation displayed by these deposits probably was caused by submarine slides. The trench-wedge facies (Unit II) is characterized by an upward-coarsening and upwardthickening succession of terrigenous turbidites, with interbeds of hemipelagic mud. The trench-wedge deposits reach a total structural

\footnotetext{
'Hill, I.A., Taira, A., Firth, J.V., et al., 1993. Proc. ODP, Sci. Results, 131: College Station, TX (Ocean Drilling Program).

${ }^{2}$ Department of Geological Sciences, University of Missouri, Columbia, MO 65211, U.S.A.

${ }^{3}$ Department of Geology, University of Leicester, Leicester LE1 7RH, United Kingdom.

${ }^{4}$ Scripps Institution of Oceanography, University of California, La Jolla, CA 92093. U.S.A.
}

thickness of approximately $600 \mathrm{~m}$; partial duplication of the section has occurred because of offset along the frontal thrust of the accretionary prism (Fig. 2). A transitional facies (Unit III) displays sedimentologic characteristics of both the outer marginal trench wedge and the upper part of the abyssal-plain succession, in that it contains both thin silty turbidites and layers of volcanic ash, together with the dominant lithology of hemipelagic mudstone. The composition and provenance of these trench-slope and trench-wedge deposits have been discussed at length by Underwood et al. (this volume).

Unit IV (Shikoku Basin deposits) begins at about $620 \mathrm{mbsf}$ (Fig. 2). These abyssal-floor sediments are dominated by strongly bioturbated hemipelagic mudstones. Subunit IVa contains abundant, well-defined layers of volcanic ash and lithified tuff, whereas Subunit $\mathrm{IVb}$ is nearly devoid of discrete volcaniclastic interlayers. The basal décollement zone of the Nankai accretionary prism occurs at a depth of 945-964 mbsf at Site 808, within the middle of the hemipelagites of Subunit IVb. The lowermost unit of the sedimentary succession (Unit V) contains thick layers of graded and cross-stratified rhyolitic tuff and variegated hemipelagic mudstone and claystone of middle Miocene age (13.6 Ma). Basaltic basement of the Shikoku Basin occurs at a depth of approximately $1290 \mathrm{mbsf}$ (Fig. 2).

In total, the stratigraphic succession outlined above follows the paradigm of subduction-zone sedimentation and tectonics (e.g., Piper et al., 1973; von Huene, 1974; Seely et al., 1974). The segment of subducting oceanic plate penetrated at Site 808 , with its cover of 


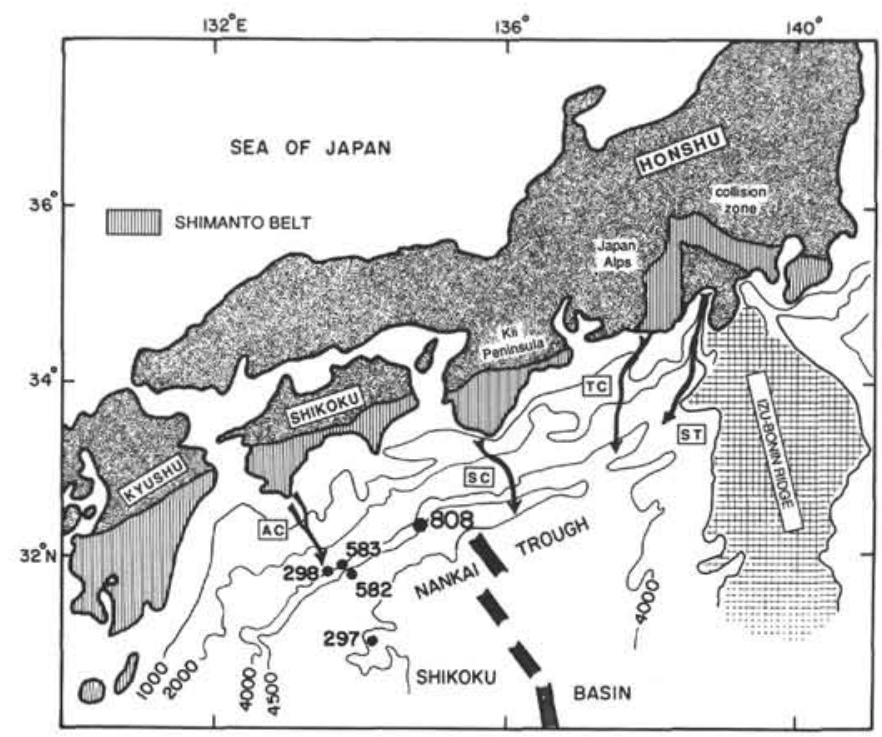

Figure 1. Index map showing the regional geography and bathymetry (in meters) of the study area in southwest Japan. Numbers refer to DSDP and ODP site localities. Stippled pattern identifies outcrops of the Shimanto Belt, and large arrows symbolize major submarine canyons (see Underwood et al., this volume). Lined pattern in the center of Shikoku Basin marks the position of the extinct spreading center. $\mathrm{AC}=$ Ashizuri Canyon, $\mathrm{SC}=$ Shiono-misaki Canyon, $\mathrm{ST}=$ Suruga Trough, and $\mathrm{TC}=$ Tenryu Canyon .

slowly accumulated Miocene to Pleistocene hemipelagic mud, entered the trench environment at about $0.46 \mathrm{Ma}$; at that time, the abyssalplain deposits started to experience rapid burial beneath terrigenous turbidites. Frontal accretion of the sediment then occurred via offscraping at the prism toe; in addition, underplating has added material toward the rear of the wedge (Moore, 1989; Moore et al., 1990; Taira et al., 1992).

Site 808 is located above the frontal thrust of the Nankai accretionary prism (Taira et al., 1992). The drilling plans for Leg 131 were designed to address three major thematic issues within this dynamic setting: (1) clarification of how pore fluids and hydrologic processes influence the chemical and physical evolution of an accretionary prism; (2) documentation of the mechanical state and physical properties of deformed sediments, both above and below a prism's décollement; and (3) analysis of structural fabrics and deformation styles near a prism's toe (Shipboard Scientific Party, 1991a).

Shipboard analyses of interstitial water chemistry led to several important observations regarding the hydrogeology of the Nankai accretionary wedge: (1) there is a pronounced reduction in chloride concentrations below about $570 \mathrm{mbsf}$, and the lowest concentrations occur below the décollement zone at $~ 1040$ to $1080 \mathrm{mbsf}$; (2) changes in concentration gradients of most dissolved chemical constituents occur between 400 and $600 \mathrm{mbsf}$; these changes are diffuse but generally coincide with the lithologic transition from the marginal trench-wedge facies (Subunit IIc) into interlayered ash deposits and mudstones of the Shikoku Basin (Subunit IVa); (3) changes in some aqueous constituents (particularly an increase in $\mathrm{H}_{4} \mathrm{SiO}_{4}$, but also Ca, $\mathrm{Mg}$, and $\mathrm{SO}_{4}$ ) occur at the lithologic boundary near $820 \mathrm{mbsf}$ (contact between Subunits IVa and IVb); and (4) stratigraphic intervals with abundant layers of volcanic ash (560-820 mbsf) show large variations in dissolved silica concentrations, together with more subtle anomalies in dissolved calcium, lithium, and strontium (Shipboard Scientific Party, 1991b). Collectively, these pore-water data illustrate the effects of significant sediment diagenesis and fluid-sediment exchange within the accretionary prism. A complete geochemical understanding of the accretionary prism, however, also requires accurate measurements of bulk-sediment mineralogy and geochemistry, unequivocal

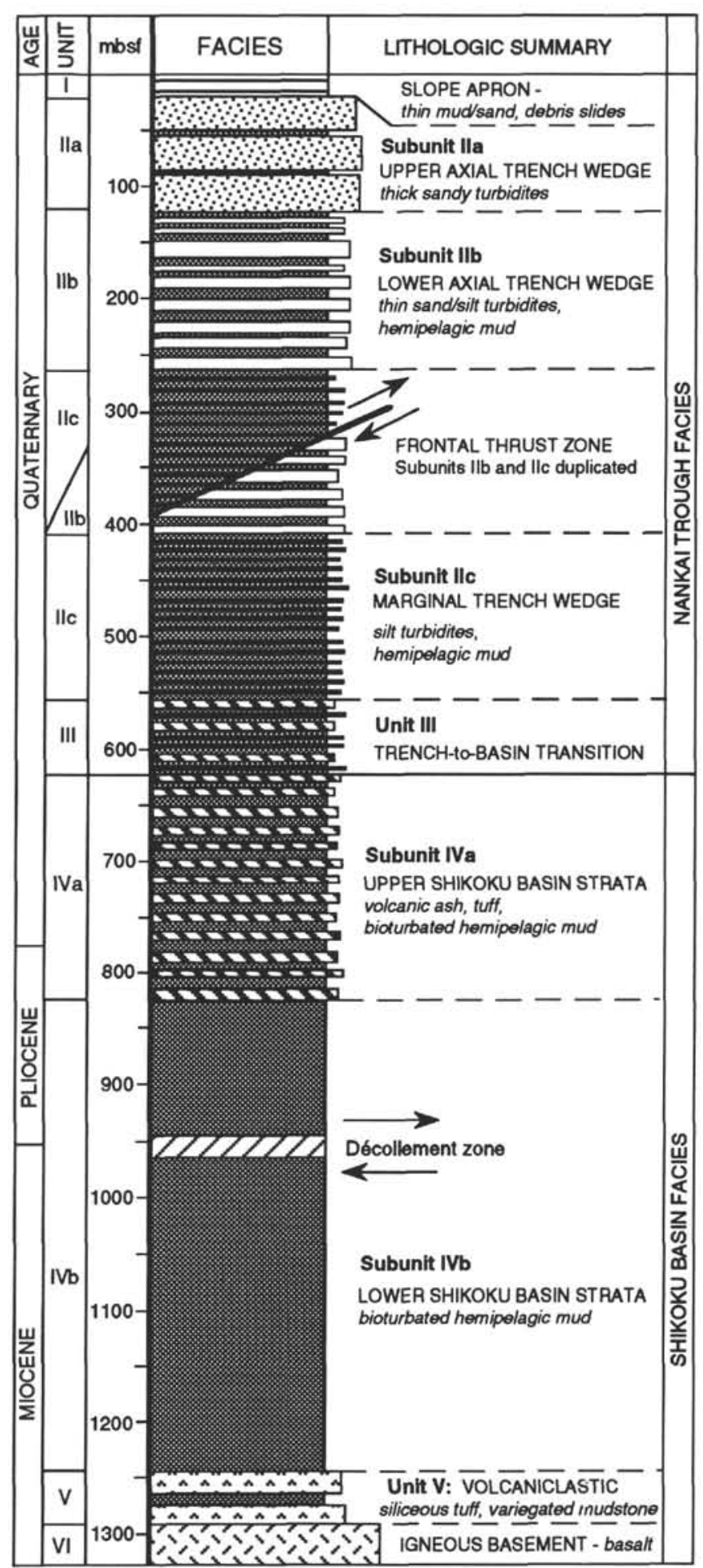

Figure 2. Stratigraphic column for Site 808. Modified from Shipboard Scientific Party (1991b).

recognition of diagenetic mineral reactions, and proper assessments of the chemical effects of volcanic-glass alteration. This paper provides a summary of the results of shore-based analytical work designed to provide such data.

Many subduction zones are characterized by relatively low geothermal gradients due to the subduction of old oceanic lithosphere (e.g., Yamano et al., 1982; Reck, 1987). Under these typical circum- 
stances, the documentation of important diagenetic reactions is impeded because the critical temperature conditions occur beyond the depth limits of conventional Deep Sea Drilling Project (DSDP)/ODP boreholes. Conversely, the Nankai Trough is a region of high heat flow triggered by the subduction of relatively young Shikoku Basin lithosphere (Yamano et al., 1984). Present-day heat flow is at a maximum near Site 808, and this is due, at least in part, to its location near the crest of the extinct spreading ridge (Ashi and Taira, in press). The last phase of volcanic activity in the Shikoku Basin ended about $12 \mathrm{Ma}$ (Chamot-Rooke et al., 1987). Empirical models of thermal decay for oceanic lithosphere predict heat-flow values of $136 \mathrm{~mW} / \mathrm{m}^{2}$ (Parsons and Sclater, 1977) to $145 \mathrm{~mW} / \mathrm{m}^{2}$ (Lister, 1977) for a crustal age of $12 \mathrm{Ma}$. The present-day heat flow at Site 808 is equal to approximately $129 \mathrm{~mW} / \mathrm{m}^{2}$, and the average linear geothermal gradient within the upper $350 \mathrm{~m}$ of the accretionary prism is $\sim 110^{\circ} \mathrm{C} / \mathrm{km}$ (Shipboard Scientific Party, 1991b; Yamano et al., 1992). Thus, Site 808 is ideally suited for studies of early sediment diagenesis at relatively shallow depths.

The primary purpose of this paper is to synthesize the results of extensive shore-based analyses of clay mineralogy, clay-mineral diagenesis, and bulk-sediment geochemistry. We also compare data sets from Site 808 with previous results from DSDP Legs 31 and 87 . A secondary objective is to place these data and interpretations into the broader thematic context of fluid-sediment interactions within the Nankai accretionary prism. In particular, we address the possible roles of in-situ dehydration reactions and importation of pore water in the vicinity of Site 808 .

\section{METHODS \\ X-ray Diffraction}

Estimates of the relative percentages of dominant clay minerals are based on integrated peak areas calculated from digital X-ray diffraction (XRD) data, using the basal reflections produced by oriented aggregates saturated with ethylene glycol (Fig. 3). Complete descriptions of sample preparation, XRD scanning parameters, computer processing of digital output, and error analysis have been presented by Underwood et al. (this volume). All integrated peak areas were calculated using Scintag software, following a background correction and deconvolution of each peak. Separate measurements were made for the $<2-\mu \mathrm{m}$ size fraction and the 2- to $6-\mu \mathrm{m}$ size fraction. In addition, two sets of weighting factors were used to calculate relative percentages of smectite, illite, and chlorite + kaolinite. The first set of factors, from Biscaye (1965), employs a $1 \times$ correction for the smectite $(17 \AA)$ peak area, $2 \times$ for the composite chlorite + kaolinite $(7 \AA)$ peak area, and $4 \times$ for the illite $(10 \AA)$ peak area (Fig. 3). Because of the overlap between the chlorite (002) and kaolinite (001) reflections, selected samples were boiled in $\mathrm{HCl}$ and analyzed a second time to establish the approximate amount of kaolinite present (Starkey et al., 1984). By doing this, we showed that chlorite alone accounts for $92 \%$ to $80 \%$ of the composite $7 \AA$ peak, with an average of $86 \%$.

It is important to note that we did not attempt to estimate the relative percentages of illite/smectite (I/S) mixed-layer clay with respect to the total clay-mineral population. Such estimates can be made via peak subtraction methods, in which the (001) peak intensities are compared after treatment with ethylene glycol (to expand the $17 \AA$ smectite lattice) and after heating (to collapse the lattice to $10 \AA$ ). One major problem, however, is that weighting factors for the I/S components vary depending on the relative proportions of the two interlayered minerals (Reynolds, 1983). Estimates based on the size of composite peaks are also flawed because of low peak intensities and peak interference from discrete illite. Although corrections for peak interference can be made, the error increases with increasing proportions of discrete illite and increasing amounts of illite interlayers (Srodon, 1981). In most of our samples from Site 808, the peak intensities associated with the composite $(001 / 002)$ peak (at $\sim 9^{\circ}-10^{\circ} 2 \theta$ ) and the composite $\left(002 / 003\right.$ ) peak (at $\sim 16^{\circ}-17^{\circ} 2 \theta$ ) are quite subdued relative to the robust peaks produced by the discrete smectite $(001)$, illite $(001)$, and chlorite
(002) basal reflections (Fig. 3). In many cases the mixed-layer peak intensities were barely detected above background, and their positions had to be determined visually using an interactive graphic display. In effect, the reflections produced by small amounts of mixed-layer clay probably have been incorporated into the XRD peak areas used to estimate both illite and smectite percentages.

Duplicate runs for clay-mineral percentages resulted in standard deviations about mean values of approximately 1\% (Orr, 1992). However, tests of accuracy, based on mixtures of clay-mineral standards and known weight percentages, show that the error associated with the Biscaye (1965) weighting factors can be as high as $20 \%$ (Underwood et al., this volume). A second set of weighting factors, derived from the analyses of 16 different mixtures of the chlorite, illite, and smectite standards, reduces the maximum error to approximately $10 \%$ and the average error to less than $5 \%$. These peak-area weighting factors are: smectite $(001)=1 \times$; illite $(001)=8 \times$; and chlorite $(002)+$ kaolinite $(001)=1.8 \times$ (Underwood et al., this volume). In reality, the correction factors change with the absolute abundance of each clay mineral; moreover, the correction for illite is sensitive to the degree of illite crystallinity and the above-mentioned peak broadening caused by interference from I/S. Thus, we stress that the main value of these analyses is to show changes or gradients in relative clay-mineral abundances, rather than absolute percentages.

Several methods exist to calculate the relative percentages of illite and smectite crystallites in mixed-layer phases (Reynolds and Hower, 1970; Srodon, 1980, 1981, 1984; Tomita et al., 1988; Watanabe, 1988; Moore and Reynolds, 1989; Inoue et al., 1989). For heterogeneous detrital assemblages, many of these techniques are unreliable because of low peak intensities and/or peak interference by discrete illite and quartz. We employed the technique of Moore and Reynolds (1989), which is based on the angular separation $\left(\Delta^{\circ} 2 \theta\right)$ between the composite illite-(001)/smectite-(002) reflection (at $\sim 9^{\circ}$ to $10^{\circ} 2 \theta$ ) and the composite illite-(002)/smectite-(003) reflection (at $\sim 16^{\circ}$ to $17^{\circ} 2 \theta$ ). The accuracy of this technique has been established in two ways (Hathon, 1992): first, by comparing diffractograms for a diverse set of 22 natural clay-mineral specimens with synthetic computer-generated XRD patterns, using the NEWMOD software package (Moore and Reynolds, 1989); and second, by comparing the calculated percentages with visual counts of I/S ratios obtained from high-resolution transmission electron micrographs (TEM) (see also Veblen et al., 1990). The average errors in XRD estimates of interlayer smectite percentage are $2 \%$, based on NEWMOD models, and $8 \%$ based on TEM images (Hathon, 1992).

Most of our calculations of I/S interlayer percentages are based on the $<2-\mu \mathrm{m}$ size fraction, although splits of the $0.2-\mu \mathrm{m}$ size fraction also were analyzed for 13 representative specimens in an attempt to distinguish between detrital (coarser grained) and authigenic (finer grained) constituents. In addition, representative samples were analyzed under three different conditions (air-dried, glycol-saturated, and heated to $375^{\circ} \mathrm{C}$ ) to make sure that the low-intensity peaks in question conformed to the expected behavior of mixed-layer illite-smectite. In all cases, heating caused a collapse of the smectite layers and produced diffraction patterns identical to those of discrete illite; similarly, saturation with ethylene glycol shifted the composite I/S reflections due to expansion of the smectite interlayers (Fig. 3).

\section{Chemical Analyses}

$\mathrm{X}$-ray fluorescence (XRF) spectrometry was used to detect concentrations of major element oxides (weight percentage, or wt\%), together with selected minor and trace elements (ppm). All such data come from analyses of bulk samples. Instrumentation, sample preparation (fusion disks and pressed powder briquettes), XRF techniques, and error analysis have been described in detail by Pickering et al. (this volume). The data report of Pickering et al. (this volume) also contains tables of data and plots showing concentrations of each individual element. 

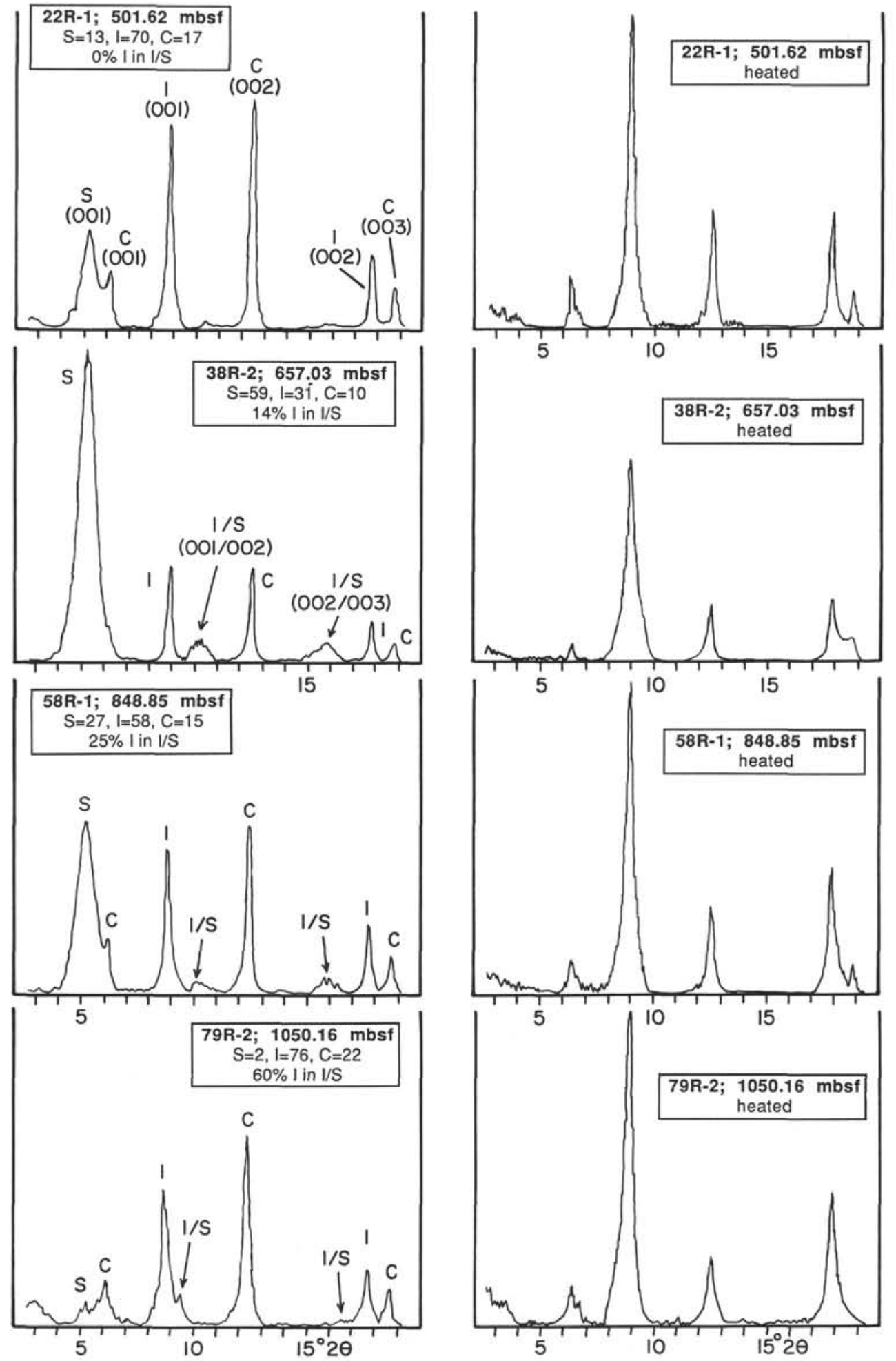

Figure 3. Representative examples of X-ray diffractograms (plotted after background correction of digital data), showing peaks used to calculate clay-mineral percentages and illite content for I/S mixed-layer clays. Examples on the left are for specimens saturated with ethylene glycol; examples on the right are for the same specimens following heating to $375^{\circ} \mathrm{C}$ to collapse the lattice of expandable clay minerals. Clay-mineral percentages are based on the integrated areas of the glycolated smectite $(001)$, illite $(001)$, and chlorite $(002)+$ kaolinite $(001)$ peaks, following deconvolution of each peak. Calculations of I/S ratios are based on the angular separation between the composite illite $(001) /$ smectite $(002)$ peak at $9.0^{\circ}-10.3^{\circ} 2 \theta$ and the illite $(002) /$ smectite $(003)$ peak at $15.8^{\circ}-17.4^{\circ} 2 \theta$, using glycolated specimens (Moore and Reynolds, 1989). Note that with small amounts of U/S clay (e.g., Section 131-808C-79R-2), the accurate identification of low-intensity peak positions becomes problematic. See Underwood et al. (this volume) for a complete discussion of peak-area weighting factors and error analysis. 


\section{RESULTS}

\section{Clay Mineralogy and Diagenesis}

It is important to compare the results of detailed clay-mineral analyses (fine fraction) with bulk-sample mineralogy at Site 808 . Unfortunately, the absolute accuracy of shipboard XRD analyses of random bulk powders was affected by the inherent problems associated with peak interference, peak-intensity weighting factors, and amorphous components such as volcanic glass and biogenic silica (Shipboard Scientific Party, 1991b). Those results clearly demonstrate, however, that the most abundant mineral in most of the samples is quartz, with relative percentages of roughly $40 \%$ to $60 \%$ (Fig. 4). The relative content of plagioclase decreases downsection and is generally between $20 \%$ and $40 \%$. Calculated relative-percentages of calcite match fairly closely the results of chemical analyses for carbonate content; those values are typically less than $10 \%$ within the trench-wedge facies and less than $30 \%$ within the finer grained Shikoku Basin deposits (Shipboard Scientific Party, 1991b). Finally, the total clay-mineral population falls between $10 \%$ and $30 \%$ of the bulk sample (Fig. 4).

The clay mineralogy of the trench-wedge facies (both hemipelagic muds and the fine-grained matrix washed from sandy and silty turbidites) has been documented in detail elsewhere (Underwood et al., this volume). In brief, the XRD results are quite uniform within the upper $600 \mathrm{~m}$ of the stratigraphic section (Fig. 5), and there is very little difference between the hemipelagic muds and the turbiditematrix clays. Detrital illite is clearly the most abundant constituent (regardless of which weighting factors are used to normalize the peak areas), followed by undifferentiated chlorite + kaolinite, then discrete smectite (Fig. 5). The kaolinite content probably amounts to no more than about $3 \%$ to $5 \%$ of the total clay-mineral population, based on selected samples that were boiled in $\mathrm{HCl}$ to remove the chlorite $(002)$ peak interference. Chlorite + kaolinite content increases by about $5 \%$ to $10 \%$ in the fine-silt fraction, relative to the $<2-\mu \mathrm{m}$ size fraction (Fig. 5). Based on measurements of illite crystallinity and illite-mica $b_{\mathrm{o}}$ lattice spacing, it is likely that the trench-wedge detritus was eroded from geologic units that include abundant lower greenschist-facies meta-sedimentary successions (Underwood et al., this volume). The amount of detrital smectite derived from subaerial weathering of volcanic rocks is relatively small. Our provenance interpretations for the fine-grained sediments reinforce previous contentions of Taira and Niitsuma (1986), who suggested that the sand-sized sediment came largely from the Japan Alps, which had formed in the collision zone between the Izu-Bonin arc and the Honshu arc (Fig. 1).

One of the challenges of interpreting mineralogic changes throughout the section at Site 808 is to separate the effects of changing detrital provenance from the effects of diagenetic alteration. Sediments within the Nankai trench-wedge facies accumulated at exceptionally rapid rates of approximately $1380-780 \mathrm{~m} / \mathrm{m}$.y. (Shipboard Scientific Party, 1991b). Conversely, sediment accumulation rates calculated for the Shikoku Basin hemipelagic deposits (below the base of Unit III) drop off significantly, to values of approximately 210 to $10 \mathrm{~m} / \mathrm{m}$.y. This change in the overall style of sedimentation reflects the dramatic difference between the turbidite-dominated trench wedge and slow fallout of suspended sediment onto the floor of the Shikoku Basin. In addition, the upper subunit of the Shikoku Basin is enriched in discrete layers of volcanic ash and lithified tuff. Significantly, this transition into the abyssal facies of Shikoku Basin corresponds to a shift in clay mineralogy, as defined by increases in the content of smectite (Table 1; Fig. 5). Shipboard XRD data also document the presence of zeolites (undifferentiated clinoptilolite/heulandite) as alteration products of the ash within Subunit IVa. The accumulation of ash and the content of smectite in mudstones appear to be genetically related.

The gradual enrichment of smectite, which actually begins at the top of Unit III, is much more obvious in the $<2-\mu \mathrm{m}$ size fraction, as compared to the 2- to 6- $\mu \mathrm{m}$ size split (Fig. 5). Maximum values of

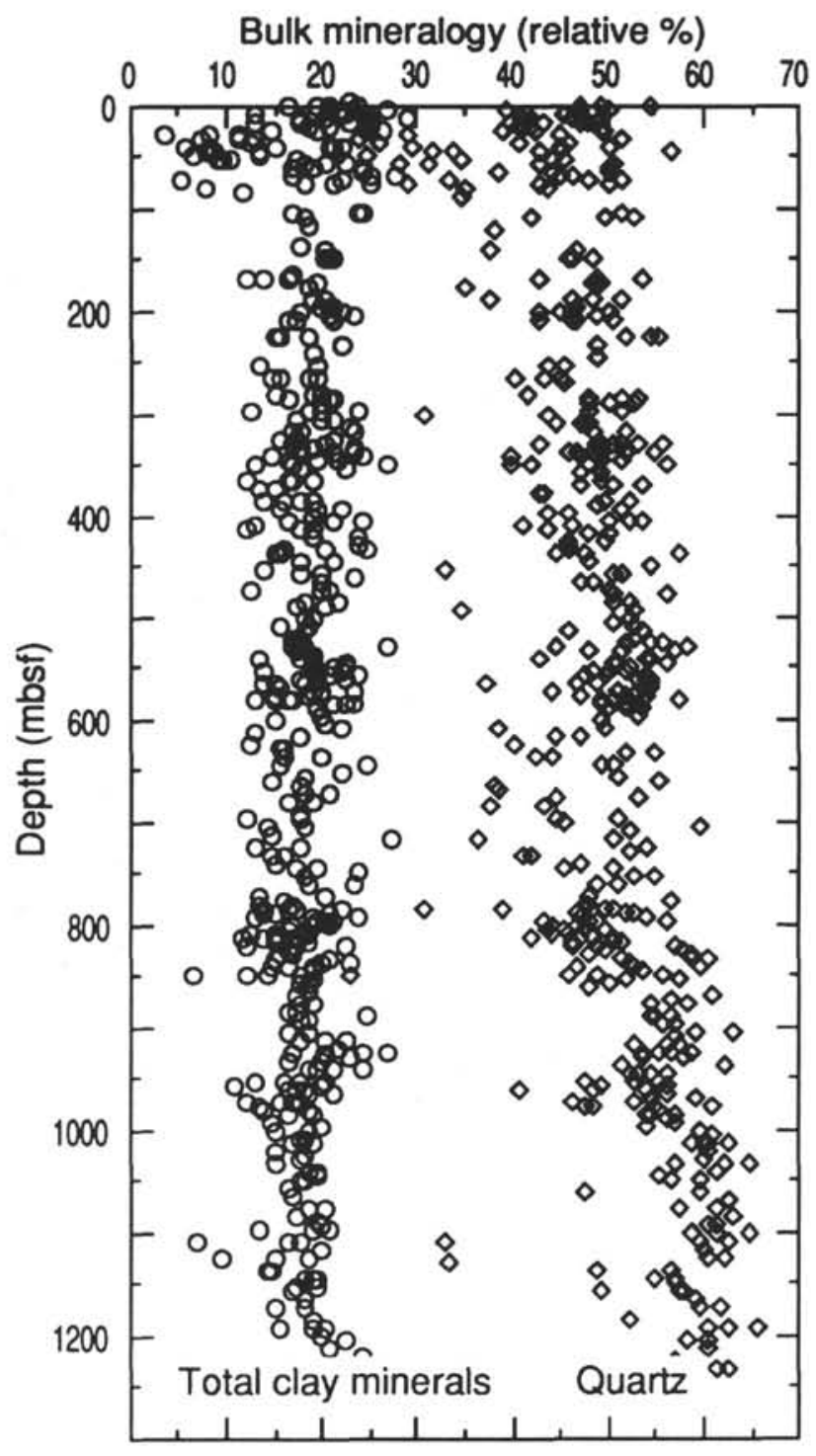

Figure 4. Summary of shipboard X-ray diffraction measurements of bulk mineralogy, showing relative percentages of quartz and total clay minerals at Site 808. Other important constituents include feldspar and calcite. Modified from Shipboard Scientific Party (1991b).

$35 \%-40 \%$ smectite occur at a stratigraphic position of $\sim 800$ mbsf. Superimposed on this trend are local spikes in smectite percentage (up to $70 \%$ to $90 \%$ ), which mark the presence of bentonite layers. These mudstones do not display any obvious differences in texture or color. The spot occurrences of bentonites within a lithology that appears to be homogeneous bioturbated mudstone leads us to suspect that other smectite-rich intervals remain undetected within the Shikoku Basin deposits. Below a depth of about 820 mbsf, the smectite content drops off steadily to the base of Subunit IVb, and there are no clay-mineral anomalies associated with the décollement zone (945-964 mbsf). Finally, clay-mineral abundances within the volcaniclastic succession of Unit V are very erratic (Fig. 5), depending on whether specimens are from tuff layers (smectite-rich) or from variegated interbeds of hemipelagic mudstone (illite-rich).

Examination of the I/S mixed-layer phase shows that smectite diagenesis becomes an important factor within the depth range of Subunit IVb (Fig. 6). Disordered $(\mathrm{R}=0$ ) mixed-layer clays were first detected above the background noise in the $<2-\mu \mathrm{m}$ size fraction at a corresponding depth of $555 \mathrm{mbsf}$, and there is a monotonic increase in 


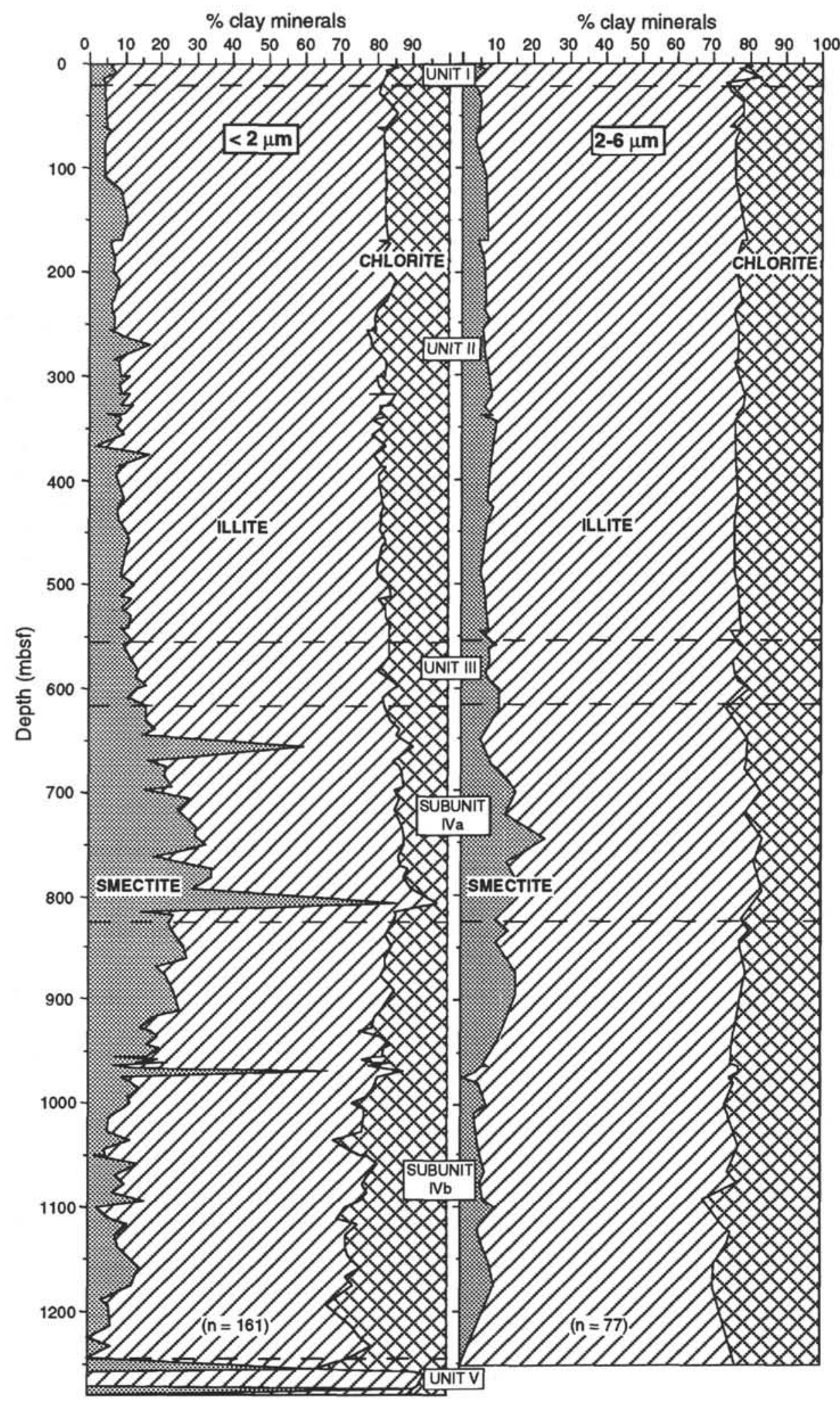

Figure 5. Relative percentages of smectite, illite, and chlorite + kaolinite at Site 808 . These calculations are based on integrated peak areas (glycolated) and weighting factors established at the University of Missouri (Underwood et al., this volume). Separate analyses were completed for the $<2-\mu \mathrm{m}$ and $2-6-\mu \mathrm{m}$ size fractions. See Underwood et al. (this volume) and Table 1 for a complete listing of data, including results based on the peak-area weighting factors of Biscaye (1965). 
Table 1. X-ray diffraction data for hemipelagic mud samples, Shikoku Basin facies.

\begin{tabular}{|c|c|c|c|c|c|c|c|c|c|c|c|}
\hline & & & & & $<2-\mu \mathrm{m}$ & ze fracti & & & & & \\
\hline & & & & & & Esti & ated min & ral perce & tage & & \\
\hline & & Integrate & peak are & (counts) & & caye fac & & & sour fa: & & Integrated \\
\hline $\begin{array}{c}\text { Sample } \\
(\mathrm{cm})\end{array}$ & $\begin{array}{l}\text { Depth } \\
\text { (mbsf) }\end{array}$ & Smectite & Illite & Chlorite & $S(\%)$ & $\mathrm{I}(\%)$ & $\mathrm{C}(\%)$ & $S(\%)$ & $I(\%)$ & $\mathrm{C}(\%)$ & Smectite \\
\hline $131-808 \mathrm{C}$. & & & & & & & & & & & \\
\hline $35 R-5,83$ & 633.03 & 17904 & 9280 & 9875 & 24 & 50 & 26 & 16 & 68 & 16 & \\
\hline $36 \mathrm{R}-2,123$ & 638.63 & 21194 & 9527 & 8562 & 28 & 50 & 22 & 19 & 68 & 14 & \\
\hline $37 \mathrm{R}-1,40$ & 645.90 & 30405 & 17405 & 15988 & 23 & 53 & 24 & is & 70 & 15 & 4745 \\
\hline $38 \mathrm{R}-2,63$ & 657.03 & 94818 & 6148 & 8477 & 70 & 18 & 12 & 60 & 31 & 10 & \\
\hline $39 \mathrm{R}-5,10$ & 670.60 & 24177 & 11935 & 12008 & 25 & 50 & 25 & 17 & 68 & 15 & 7071 \\
\hline $40 \mathrm{R}-2,6$ & 675.76 & 44441 & 16463 & 15532 & 31 & 47 & 22 & 22 & 65 & 14 & 6627 \\
\hline $41 \mathrm{R}-1,92$ & 684.72 & 25672 & 10047 & 8454 & 31 & 49 & 20 & 21 & 66 & 13 & 8357 \\
\hline $42 \mathrm{R}-3,50$ & 697.00 & 30370 & 10413 & 8939 & 34 & 46 & 20 & 23 & 64 & 12 & 10692 \\
\hline $42 R-4,57$ & 698.57 & 31088 & 16646 & 15695 & 24 & 52 & 24 & 16 & 69 & 15 & \\
\hline $43 \mathrm{R}-2,70$ & 705.40 & 36425 & 9381 & 9542 & 39 & 40 & 21 & 28 & 58 & 13 & \\
\hline $44 \mathrm{R}-4,24$ & 717.14 & 38816 & 11725 & 12670 & 35 & 42 & 23 & 25 & 60 & 15 & 8006 \\
\hline $46 \mathrm{R}-2,29$ & 733.49 & 29304 & 6919 & 6773 & 42 & 39 & 19 & 30 & 57 & 13 & \\
\hline $47 \mathrm{R}-1,21$ & 741.61 & 53642 & 13056 & 12395 & 41 & 40 & 19 & 30 & 58 & 12 & 18287 \\
\hline $48 \mathrm{R}-1,90$ & 752.00 & 40173 & 8398 & 8406 & 44 & 37 & 19 & 33 & 55 & 12 & \\
\hline $49 \mathrm{R}-1,72$ & 761.42 & 32286 & 14621 & 13355 & 27 & 50 & 23 & 19 & 67 & 14 & 6521 \\
\hline $50 \mathrm{R}-1,12$ & 770.52 & 38717 & 8924 & 9180 & 42 & 38 & 20 & 31 & 56 & 13 & \\
\hline $50 R-3,48$ & 773.10 & 38713 & 7688 & 6768 & 47 & 37 & 16 & 34 & 55 & II & \\
\hline 5IR-1, 86 & 780.96 & 48527 & 9395 & 9597 & 46 & 36 & 18 & 34 & 53 & 12 & \\
\hline 52R-3, 19 & 792.99 & 29963 & 7732 & 5906 & 41 & 43 & 16 & 29 & 60 & 10 & 10768 \\
\hline $53 \mathrm{R}-6,32$ & 807.22 & 110269 & 1847 & 2258 & 90 & 6 & 4 & 85 & 11 & 3 & \\
\hline $54 \mathrm{R}-4,80$ & 814.40 & 23302 & 13604 & 12705 & 23 & 53 & 25 & 15 & 70 & 15 & \\
\hline $55 \mathrm{R}-1,13$ & 818.83 & 52667 & 16908 & 17858 & 34 & 43 & 23 & 24 & 61 & 15 & 6533 \\
\hline SSR-S, 93 & 825.63 & 36735 & 12697 & 14143 & 32 & 44 & 24 & 22 & 62 & 16 & \\
\hline $56 \mathrm{R}-1,40$ & 828.80 & & & & & & & & & & 7730 \\
\hline $57 R-1,37$ & 838.47 & 37780 & 11482 & 15275 & 33 & 40 & 27 & 24 & 58 & 17 & 8070 \\
\hline S8R-1, 145 & 848.85 & 36521 & 9856 & 11737 & 37 & 40 & 24 & 27 & 58 & 15 & \\
\hline $59 R-2,56$ & 859.16 & 33573 & 8312 & 11651 & 37 & 37 & 26 & 28 & 55 & 17 & \\
\hline $60 \mathrm{R}-1,137$ & 868.17 & 28601 & 11787 & 14567 & 27 & 45 & 28 & 19 & 63 & 18 & 12035 \\
\hline $6 \mid R-1.7$ & 876.57 & 28312 & 9864 & 13662 & 30 & 41 & 29 & 21 & 60 & 19 & \\
\hline $62 \mathrm{R}-3,145$ & 890.55 & 33698 & 10971 & 11943 & 33 & 43 & 24 & 24 & 61 & 15 & 11265 \\
\hline $64 \mathrm{R}-3,130$ & 909.80 & 37171 & 10275 & 14991 & 34 & 38 & 28 & 25 & 56 & 18 & \\
\hline 65R-1, 12 & 915.22 & 25209 & 10445 & 15249 & 26 & 43 & 31 & 19 & 61 & 20 & \\
\hline $66 R-2,108$ & 927.38 & 27945 & 15716 & 23162 & 20 & 46 & 34 & 14 & 64 & 21 & \\
\hline $66 \mathrm{R}-4,108$ & 930.38 & 24187 & 10119 & 18934 & 24 & 39 & 37 & 17 & 58 & 24 & \\
\hline $67 R-1,141$ & 935.91 & 36532 & 14719 & 19531 & 27 & 44 & 29 & 19 & 62 & 19 & 8749 \\
\hline 68 R-1. 38 & 944.58 & 37409 & 18947 & 20064 & 24 & 49 & 26 & 17 & 67 & 16 & \\
\hline $68 \mathrm{R}-1,130$ & 945.50 & 28117 & 10885 & 13972 & 28 & 44 & 28 & 20 & 62 & 18 & \\
\hline $69 \mathrm{R}-1.11$ & 953.91 & 17813 & 8669 & 10833 & 24 & 47 & 29 & 17 & 65 & 18 & \\
\hline $69 \mathrm{R}-2,38$ & 955.68 & 11779 & 13509 & 17165 & 12 & 54 & 34 & 8 & 72 & 20 & \\
\hline $69 \mathrm{R}-2,133$ & 956.63 & 25400 & 9223 & 17094 & 26 & 38 & 35 & 20 & 57 & 24 & 2841 \\
\hline $69 \mathrm{R}-4,63$ & 958.93 & 19349 & 11762 & 16610 & 19 & $\begin{array}{l}50 \\
47\end{array}$ & 33 & 13 & 66 & 21 & 4793 \\
\hline $69 \mathrm{R}-5,11$ & 959.91 & 40079 & 14290 & 15864 & 31 & 44 & 25 & 22 & 62 & 16 & 3726 \\
\hline $70 \mathrm{R}-1.25$ & 963.65 & 9640 & 10658 & 14956 & 12 & 52 & 36 & 8 & 70 & 22 & \\
\hline $70 \mathrm{R}-1.93$ & 964.33 & 24516 & 16259 & 18327 & 19 & 52 & 29 & 13 & 69 & 18 & 1483 \\
\hline $70 \mathrm{R}-4,34$ & 968.24 & 254265 & 10171 & 26258 & 73 & 12 & 15 & 66 & 21 & 12 & 576 \\
\hline $71 R-1,125$ & 974.35 & 14046 & 13077 & 15891 & 14 & 53 & 32 & 10 & 71 & 19 & 3365 \\
\hline $72 R-1,143$ & 984.23 & 19495 & 11124 & 15955 & 20 & 46 & 33 & 14 & 65 & 21 & \\
\hline $73 R-2,110$ & 994.70 & 19741 & 14567 & 22336 & 16 & 47 & 36 & II & 66 & 23 & 4618 \\
\hline $73 \mathrm{R}-6,48$ & 1000.08 & 19814 & 12990 & 24970 & 16 & 43 & 41 & 12 & 62 & 27 & \\
\hline $74 R-2,16$ & 1003.46 & 14699 & 12716 & 19495 & 14 & 49 & 37 & 10 & 67 & 23 & 2547 \\
\hline $75 \mathrm{R}-2,35$ & 1013.10 & 8727 & 13132 & 19305 & 9 & 53 & 39 & 6 & 71 & 23 & \\
\hline $76 R-5,30$ & 1026.80 & 5483 & 8795 & 13113 & 8 & 53 & 39 & 6 & 71 & 24 & \\
\hline $77 R-3,145$ & 1034.35 & 10082 & 6133 & 15200 & 16 & 38 & 47 & 12 & 57 & 32 & 4846 \\
\hline $78 \mathrm{R}-4.28$ & 1043.88 & 7476 & 12954 & 23662 & 7 & 49 & 44 & 5 & 67 & 28 & \\
\hline $79 \mathrm{R}-1,73$ & 1049.03 & 6959 & 11730 & 18037 & 8 & 52 & 40 & 5 & 70 & 24 & \\
\hline $79 \mathrm{R}-2,36$ & 1050.16 & 2086 & 11954 & 15593 & 3 & 59 & 38 & 2 & 76 & 22 & \\
\hline $80 \mathrm{R}-1,28$ & 1058.08 & 32001 & 19138 & 24634 & 20 & 49 & 31 & 14 & 67 & 19 & 3270 \\
\hline $8 \mid \mathrm{R}-2,70$ & 1069.30 & 9594 & 11365 & 15831 & 11 & 52 & 37 & 7 & 70 & 22 & 3915 \\
\hline $82 \mathrm{R}-1,100$ & 1077.50 & 14676 & 12036 & 19094 & 15 & 48 & 38 & 10 & 66 & 24 & \\
\hline $83 R-1,55$ & 1086.35 & 9277 & 12000 & 16762 & 10 & 53 & 37 & 7 & 71 & 22 & 3060 \\
\hline $84 \mathrm{R}-2,56$ & 1094.06 & 19893 & 9591 & 17452 & 21 & 41 & 37 & 16 & 60 & 25 & 6872 \\
\hline $85 \mathrm{R}-2,21$ & 1100.01 & 3679 & 12135 & 22299 & 4 & 50 & 46 & 3 & 69 & 28 & \\
\hline $86 R-3,3$ & 1111.03 & 8568 & 10440 & 22612 & 9 & 44 & 47 & 6 & 63 & 31 & 2783 \\
\hline $87 R-1.14$ & 1117.17 & $\begin{array}{r}8000 \\
17161\end{array}$ & 12308 & 21337 & 16 & 45 & 39 & 11 & 64 & 25 & 3285 \\
\hline $88 R-1.37$ & 1127.27 & 7984 & 8357 & 16477 & II & 45 & 44 & 8 & 64 & 28 & 3677 \\
\hline $89 \mathrm{R}-1.93$ & 1137.53 & 8704 & 8135 & 16363 & 12 & 44 & 44 & 8 & 63 & 29 & \\
\hline $90 R-1,56$ & 1146.86 & 16004 & 11207 & 22270 & 15 & 43 & 42 & iI & 62 & 28 & 3585 \\
\hline $91 \mathrm{R}-1.59$ & 1156.49 & 21478 & 11504 & 20122 & 20 & 43 & 37 & 14 & 61 & 24 & \\
\hline $92 \mathrm{R}-1,120$ & 1166.80 & 11900 & 6663 & 14254 & 18 & 40 & 43 & 13 & 59 & 28 & 4893 \\
\hline $93 \mathrm{R}-1.25$ & 1175.55 & 13182 & 8364 & 15922 & 17 & 43 & 41 & 12 & 62 & 26 & \\
\hline $94 \mathrm{R}-2,40$ & 1186.80 & 3101 & 6418 & 14158 & 5 & 45 & 50 & 4 & 64 & 32 & \\
\hline $95 \mathrm{R}-\mathrm{I}, 14$ & 1194.74 & 6042 & 7956 & 19501 & 8 & 41 & 51 & 6 & 61 & 33 & \\
\hline $97 \mathrm{R}-1,21$ & 1214.21 & 8590 & 11207 & 19791 & 9 & 48 & 43 & 6 & 67 & 27 & \\
\hline $98 \mathrm{R}-1,7$ & 1223.77 & 0 & 8971 & 12790 & 0 & 58 & 42 & 0 & 76 & 24 & \\
\hline $99 \mathrm{R}-1,37$ & 1233.77 & 6565 & 9211 & 11859 & 10 & 55 & 35 & 6 & 73 & 21 & \\
\hline $100 \mathrm{R}-1.72$ & 1243.72 & 0 & 5771 & 9620 & 0 & 55 & 45 & 0 & 73 & 27 & 0 \\
\hline $101 R-2,22$ & 1253.92 & 15939 & 0 & 5140 & 61 & 0 & 39 & 63 & 0 & 37 & \\
\hline $101 R-4,134$ & 1258.04 & 0 & 5723 & 2565 & 0 & 82 & 18 & 0 & 91 & 9 & \\
\hline $102 \mathrm{R}-1,30$ & 1261.80 & 0 & 9466 & 2835 & 0 & 87 & 13 & 0 & 94 & 6 & \\
\hline $103 \mathrm{R}-1,101$ & 1271.91 & 0 & 17122 & 6487 & 0 & 84 & 16 & 0 & 92 & 8 & \\
\hline $103 R-3,55$ & 1274.45 & 31801 & 0 & 1788 & 90 & 0 & 10 & 91 & 0 & 9 & \\
\hline $104 \mathrm{R}-1,17$ & 1280.57 & 0 & 13408 & 7295 & 0 & 79 & 21 & 0 & 89 & 11 & \\
\hline
\end{tabular}


the proportion of illite through the remainder of the stratigraphic section. At the lithologic boundary between Subunits IVa and IVb ( $820 \mathrm{mbsf}$ ), there is about $25 \%$ to $30 \%$ illite in the I/S. The maximum amount of interlayered illite is $78 \%$, at a depth of approximately 1220 mbsf (Fig. 6). The development of a regular stacking arrangement of I/S interlayers produces a second-order superstructure reflection $\left(002^{*}\right)$ at a diffraction angle of approximately $6.5^{\circ} 2 \theta$ (Moore and Reynolds, 1989). We detected this so-called Reichweite $=1(R=1)$ ordering beginning at a depth of $1223 \mathrm{mbsf}$ in the $<2-\mu \mathrm{m}$ size fraction; $\mathrm{R}=1$ ordering occurs at a shallower depth of approximately $1100 \mathrm{mbsf}$ in the $<0.2-\mu \mathrm{m}$ size fraction (Fig. 6). This increase in the illite component of I/S clays probably has contributed to the negative gradient in discrete smectite within Subunit IVb (Fig. 5).

\section{Major Elements}

The chemical compositions of sediments from Site 808 are remarkably uniform throughout most of the section (Pickering et al., this volume). The average oxide percentages (uncorrected for ignition loss) are: $\mathrm{SiO}_{2}=64.31 ; \mathrm{Al}_{2} \mathrm{O}_{3}=16.12 ; \mathrm{Fe}_{\text {total }}=6.25 ; \mathrm{MnO}=0.40 ; \mathrm{MgO}=$ 2.50; $\mathrm{CaO}=3.28 ; \mathrm{Na}_{2} \mathrm{O}=2.68 ; \mathrm{K}_{2} \mathrm{O}=3.04 ; \mathrm{TiO}_{2}=0.70$; and $\mathrm{P}_{2} \mathrm{O}_{5}=$ 0.30 . There are no pronounced gradients as a function of depth or stratigraphic age, nor did we detect any obvious differences between the compositions of the trench-wedge deposits (Fig. 7) and those of the underlying hemipelagites of the Shikoku Basin (Fig. 8). Values of $\mathrm{Na}_{2} \mathrm{O}$ (Pickering et al., this volume) have not been corrected for residual seawater salts, so as much as $50 \%$ of the sodium may be derived from pore-water desiccation. Most of the local increases in $\mathrm{CaO}$ content occur within thin layers of calcareous mudstone, particularly within the hemipelagic deposits of Subunit IVb, where there are also local anomalies in $\mathrm{MnO}$ and $\mathrm{P}_{2} \mathrm{O}_{5}$. The major-oxide data display what appear to be erratic fluctuations within Unit V (Fig. 8), but these differences correspond to interbeds of silicic tuff and hemipelagic mudstone.

Chemical changes in sediment composition are often described in terms of elemental atomic ratios or oxide ratios of the major-element constituents relative to that of an element of low mobility, such as aluminum. The relevant ratios of oxide weight percentage for Site 808 are shown in Figure 9. There is a subtle increase in the $\mathrm{K}_{2} \mathrm{O} / \mathrm{Al}_{2} \mathrm{O}_{3}$ ratio below about $900 \mathrm{mbsf}$, as well as a slight decrease in $\mathrm{SiO}_{2} / \mathrm{Al}_{2} \mathrm{O}_{3}$ within the Shikoku Basin facies. $\mathrm{TiO}_{2} / \mathrm{Al}_{2} \mathrm{O}_{3}$ ratios shift to lower values abruptly at the top of Subunit IVa. There are no obvious chemical perturbations, however, within the décollement zone. The most obvious anomaly defined by the major elements occurs at a depth of approximately $1100 \mathrm{mbsf}$, where there are sharp increases in $\mathrm{Fe}_{\text {total }}$ l $\mathrm{Al}_{2} \mathrm{O}_{3}, \mathrm{MnO} / \mathrm{Al}_{2} \mathrm{O}_{3}$ and $\mathrm{CaO} / \mathrm{Al}_{2} \mathrm{O}_{3}$, together with a more subdued increase in $\mathrm{MgO} / \mathrm{Al}_{2} \mathrm{O}_{3}$ (Fig. 9). Within this depth interval of Subunit IVb (1087-1111 mbsf), there are varicolored bands and diffuse laminae in the bioturbated mudstones, patches of diagenetic carbonate, and local nodules of siderite (Shipboard Scientific Party, 1991b). Within Unit V, significant oscillations in the oxide ratios are associated with differences between tuff and claystone interbeds (Fig. 10).

\section{Minor and Trace Elements}

Figures 11 and 12 summarize the results of chemical analyses for most of the minor and trace elements detected by XRF (see Pickering et al., this volume, for tables of data). As with the major-oxide data, most of the samples yielded uniform elemental concentrations as a function of depth and stratigraphic age. There are subtle but consistent increases in $\mathrm{Zn}, \mathrm{Rb}$, and $\mathrm{Cu}$ with depth, and the gradient in $\mathrm{Zr}$ is slightly negative (Fig. 11). Ni and V display several isolated anomalies (both positive and negative), but there are no trends to the background values (Fig. 11). All of these elements also show departures from the background gradients within the volcaniclastic succession of Unit V. At enlarged scales, the patterns for $\mathrm{Nd}, \mathrm{Cr}, \mathrm{Co}, \mathrm{Th}, \mathrm{Sc}, \mathrm{Ga}$, and $\mathrm{Nb}$ display considerable noise, but there are no meaningful anomalies or gradients (Fig. 12). None of the minor or trace elements displays anomalous values within the décollement zone. Five elements ( $\mathrm{Ba}, \mathrm{Y}$, $\mathrm{Sr}, \mathrm{La}$, and $\mathrm{Ce}$ ) show uniform background values throughout the trench-wedge facies and most of the abyssal-plain facies, except for dramatic increases in Subunit IVb between 1087 and 1111 mbsf (Fig. 13). Ba concentrations within this anomalous zone increase by as much as two orders of magnitude, and the other elements increase by as much as $4 \times$ to $6 \times$. This is the same depth interval in which anomalies in $\mathrm{MgO} / \mathrm{Al}_{2} \mathrm{O}_{3}, \mathrm{Fe}_{\text {total }} / \mathrm{Al}_{2} \mathrm{O}_{3}, \mathrm{MnO} / \mathrm{Al}_{2} \mathrm{O}_{3}$, and $\mathrm{CaO} / \mathrm{Al}_{2} \mathrm{O}_{3}$ ratios were detected (Fig. 9). Concentrations of $\mathrm{Sr}$ also increase within the volcaniclastic facies of Unit V (Fig. 13).

\section{DISCUSSION}

\section{Clay Mineralogy}

Direct comparisons of the estimated clay-mineral percentages at Site 808 with results from nearby DSDP sites are not strictly valid because of differences in analytical technique and peak-intensity weighting factors. For example, Cook et al. (1975) reported relative abundances for all common minerals using random mounts of wholerock powders. Their findings indicate that illite is the most abundant clay mineral at both Site 297 (Shikoku Basin) and 298 (Nankai prism); smectite (montmorillonite) values are subordinate except within the Shikoku Basin at depths greater than 600 mbsf, where relative percentages for the $<2-\mu \mathrm{m}$ size fraction increase to $45 \%$ to $57 \%$. Chamley et al. (1986) likewise reported an illite-rich (30\% to 50\%) and chlorite-rich (20\% to $35 \%$ ) assemblage of clay minerals at Sites 582 and 583. Smectite relative percentages increase to $25 \%$ to $40 \%$ within lower Pleistocene and Pliocene hemipelagic deposits of the Shikoku Basin (566-749 mbsf); I/S also increases relative to other clay minerals over this same depth interval (Chamley et al., 1986).

Smectite increases considerably in Miocene mudstones from the lower parts of Holes 442,443, and 444, which were drilled near the center of the Shikoku Basin during DSDP Leg 58 (Chamley, 1980). In contrast, Pliocene-Pleistocene deposits at those reference sites are characterized by heterogeneous mixtures of smectite, illite, chlorite, mixed-layer clays, and kaolinite, similar to the clay-mineral assemblages of Nankai Trough. As suggested by Chamley et al. (1986), the changes in smectite content within the Nankai Trough stratigraphy could be a result of temporal and/or spatial differences in detrital sources (i.e., focused flux into the trench wedge vs. a more diffuse supply of abyssal-plain muds from multiple sources). Alternatively, one might attribute the enrichment of smectite and I/S clays at greater depths to in-situ replacement of volcanic glass shards and the early stages of illitization of the authigenic smectite.

Most of the overall trends in clay-mineral percentages at Site 808 agree with the results of previous workers. In particular, the percentages of smectite are relatively low, especially for a depositional environment that is bordered by active volcanic arcs. All of the data sets show increases in smectite below depths of about 500 mbsf. At Site 808 , the relative percentage of smectite reaches a maximum at a depth of approximately $800 \mathrm{mbsf}$. One major departure from the previous results is the monotonic reduction in discrete smectite beginning at a depth of about $820 \mathrm{mbsf}$; this depth range, however, is deeper than the maximum penetration of previous DSDP holes, so we have no means of assessing its regional occurrence.

There are three reasonable explanations for the depletion of smectite within Subunit IVb: (1) a change in detrital source area; (2) a change in the amount of volcanic activity and/or chemical weathering of volcanic rocks within the source area(s); and (3) clay diagenesis within the Shikoku Basin, with alteration of discrete detrital smectite to mixed-layer I/S. These explanations are not mutually exclusive, and because of the extreme physical mobility of suspended clays within surface waters and the bottom nepheloid layer, the possibility of clay-mineral homogenization following detrital influx from several subaerial sources must be considered. Several observations, however, lead us to conclude that Subunit IVb contained less smectite before the effects of diagenesis were imparted. One important consideration 


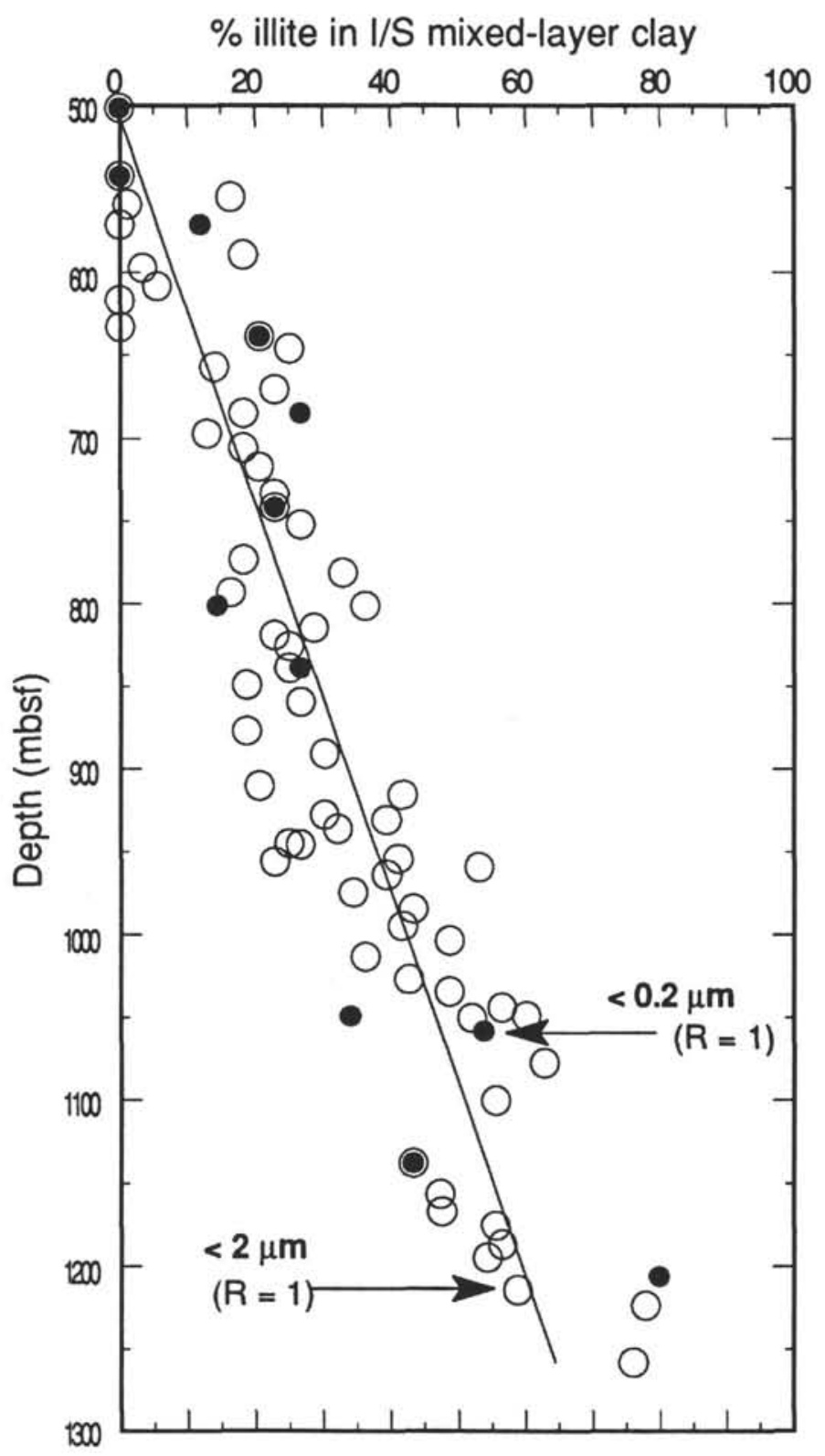

Figure 6. Estimates of percent illite in I/S mixed-layer clays at Site 808. Symbols denote two groups of size fractions: $<2-\mu \mathrm{m}$ (open circles) and $<0.2-\mu \mathrm{m}$ (solid dots). Calculations are based on the angular separation $\left(\Delta^{\circ} 2 \theta\right)$ between the composite illite $(001) /$ smectite $(002)$ peak at $9.0^{\circ}-10.3^{\circ} 2 \theta$ and the illite (002)/smectite (003) peak at $15.8^{\circ}-17.4^{\circ} 2 \theta$ (Fig. 3; Moore and Reynolds, 1989). The initial appearance of $R=1$ ordering is based on a second-order superstructure reflection $\left(002^{*}\right)$ at a diffraction angle of approximately $6.5^{\circ} 2 \theta$.

is the paucity of discrete volcanic ash layers within Subunit IVb; presumably, this lithofacies change also coincided with a reduction in the amount of disseminated glass shards which served as precursors for authigenic smectite in the mudstones. Data from discrete ash layers show that smectite begins to replace glass shards at a depth of $\sim 200$ mbsf, and below 550 mbsf the concentration of clay minerals within the ash deposits increases dramatically (Masuda et al., this volume). These data prove that the chemical conditions within Sub-unit IVb have been appropriate for smectite to form. The upper boundary of Subunit IVb also marks an abrupt termination of zeolite mineralization within the bulk mudstones, and this is probably due to an absence or reduction of glass shards as a starting product for zeolitization. Compared to Subunit IVa and Unit III, pyroclastic activity obviously was limited in the detrital source area(s) during the accumulation of Subunit IVb, which probably led to a modest amount of subaerial weathering of volcanic source rocks and formation of detrital smectite. We believe, therefore, that less detrital smectite was transported into the Shikoku Basin during its early stages of sedimentation, and less smectite was produced via in-situ alteration of disseminated ash. On the other hand, it is also clear that illitization of both detrital and authigenic smectite components becomes increasingly significant with depth, such that specimens from below 900 mbsf typically contain more than $30 \%$ illite in the I/S phase. Consequently, clay diagenesis contributed to the negative smectite gradient within Subunit IVb.

\section{Smectite-Illite Diagenesis}

Peaks produced by a composite of disordered $I / S(R=0)$ first appear in mudstone samples at a stratigraphic position of $\sim 555 \mathrm{mbsf}$ (Fig. 6). The estimated temperature at this depth bolsters the interpretation of diagenetic alteration of detrital and/or authigenic smectite to illite. The seafloor temperature at Site 808 is $\sim 2^{\circ} \mathrm{C}$ (Shipboard Scientific Party, 1991b). The average geothermal gradient recorded in the upper $350 \mathrm{~m}$ of the stratigraphic section is $\sim 110^{\circ} \mathrm{C} / \mathrm{km}$ (Shipboard Scientific Party, 1991b). If we assume that this gradient remains linear to a depth of $560 \mathrm{mbsf}$, then the temperature associated with the beginning of illitization is $\sim 65^{\circ} \mathrm{C}$. Similarly, the temperature extrapolated to $1200 \mathrm{mbsf}$ would be $\sim 130^{\circ} \mathrm{C}$. These temperatures are best viewed as maxima, however, because if one assumes constant heat flow and considers the effects of increasing thermal conductivity with depth, the thermal gradient must be nonlinear. Kastner et al. (this volume) arrived at independent estimates of thermal conditions using the $\mathrm{Mg}-\mathrm{Li}$ geothermometer; they calculated a temperature of $120^{\circ} \mathrm{C}$ at $1200 \mathrm{mbsf}$, so an average gradient of approximately $110^{\circ} \mathrm{C} / \mathrm{km}$ appears to be reasonable.

Beginning at a depth of $900 \mathrm{mbsf}\left(\sim 100^{\circ} \mathrm{C}\right)$, the I/S phase typically contains greater than $30 \%$ illite (Fig. 6). The initial appearance of $\mathrm{R}=1$ ordering in the $<2-\mu \mathrm{m}$ size fraction occurs at a depth of approximately $1220 \mathrm{mbsf}\left(\sim 135^{\circ} \mathrm{C}\right)$. In typical shales, the transition from random to ordered interlayers occurs with $60 \%$ to $70 \%$ illite layers (Bethke et al., 1986). The results from Site 808 are consistent with this general trend (Fig. 6). Within the finer size fraction $(<0.2 \mu \mathrm{m}), \mathrm{R}=1$ ordering first appears at a shallower depth of about $1060 \mathrm{mbsf}$ and at an estimated temperature of $120^{\circ} \mathrm{C}$; the illite component of the $<0.2-\mu \mathrm{m} \mathrm{I} / \mathrm{S}$ phase is about $55 \%$. This acceleration of illitization within the finer size fraction is also typical (e.g., Hower et al., 1976; Jennings and Thompson, 1986).

Temperature is the most important factor in the smectite-to-illite transition, but the reaction is affected by many other internal and external variables, such as hydraulic and differential burial pressures, host-rock porosity and permeability, water-rock ratios, pore-water chemistry, abundance of specific interlayer cations in the smectite, bulk host-rock mineralogy, the nature of lithologic interbedding, chemical composition of the precursor smectite, content of organic matter, and reaction time (Hower et al., 1976; Eberl and Hower, 1977; Eberl, 1978; Roberson and Lahann, 1981; Bruce, 1984; ColtenBradley, 1987; Yau et al., 1987; Velde and Iijima, 1988; Velde and Espitalie, 1989; Whitney, 1990). Empirical correlations of I/S ratios with burial temperature and heating time suggest that the progress of reactions can be modeled according to kinetic rate laws (Eberl and Hower, 1976; Bethke and Altaner, 1986; Pytte and Reynolds, 1989).

Because so many factors are involved, it is not surprising that starting temperatures and gradients of illitization both vary from one borehole site to another (e.g., Perry and Hower, 1970; Dypvik, 1983; Bruce, 1984; Ramseyer and Boles, 1986; Velde and Iijima, 1988; Freed and Peacor, 1989b). On the Gulf Coast, for example, the temperature range extends from $58^{\circ}$ to $92^{\circ} \mathrm{C}$ for onset of illitization, and $\mathrm{L} / \mathrm{S}$ ratios reach $70 \%$ to $80 \%$ illite at temperatures of $88^{\circ}$ to $142^{\circ} \mathrm{C}$ (Freed and Peacor, 1989b). In contrast, Tribble (1990) documented 


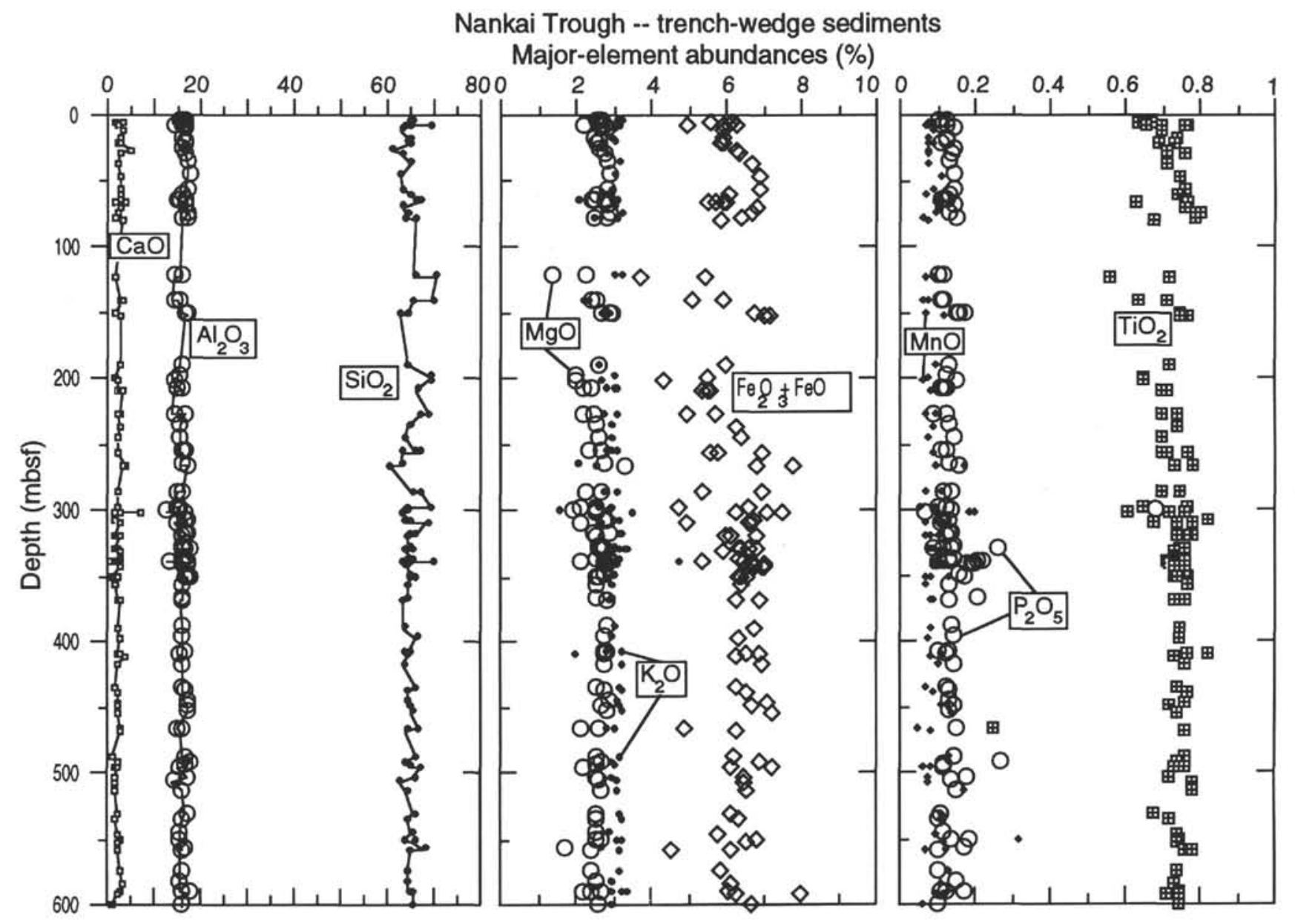

Figure 7. Plots of major-element oxides (wt \%) for Units I, II, and III at Site 808 (trench-slope, trench-wedge, and trench-to-basin transition). See Pickering et al. (this volume) for a complete listing of data.

an intriguing example from the Barbados accretionary prism, in which illitization apparently has been accelerated, such that smectite alteration began at temperatures as low as $24^{\circ} \mathrm{C}$ (see also Schoonmaker et al., 1986). Data from the Nankai accretionary prism are well within the anticipated window of burial temperature $\left(\sim 60^{\circ}\right.$ to $\left.90^{\circ} \mathrm{C}\right)$. Consequently, we see no reason to invoke special circumstances to account for the documented diagenetic trend.

According to kinetic models, I/S reaction rates slow down considerably as the mixed-layer composition approaches that of pure illite (Bethke and Altaner, 1986; Pytte and Reynolds, 1989). Higher activation energies are associated with illitic I/S, which provides one explanation for why mixed-layer phases with $15 \%$ to $20 \%$ expandable layers persist well beyond the so-called completion temperature. A second factor, in some instances, is the exhaustion of $\mathrm{K}$-feldspar in host rocks or adjacent deposits as a source for the dissolved potassium and aluminum required by the illitization reaction (Perry and Hower, 1970; Hower et al., 1976; Bruce, 1984; Jennings and Thompson, 1986).

The type of I/S ordering is also sensitive to several variables, including the geothermal gradient. For example, the change from $\mathrm{R}=0$ (disordered) to $\mathrm{R}=1$ (ordered) $\mathrm{I} / \mathrm{S}$ can occur at burial temperatures as low as $50^{\circ}$ to $80^{\circ} \mathrm{C}$, particularly where geothermal gradients are relatively low (Velde et al., 1986). In other first-cycle basins, random $(\mathrm{R}=0)$ ordering persists to temperatures of $100^{\circ}$ to $130^{\circ} \mathrm{C}$, even with geothermal gradients of $25^{\circ}$ to $30^{\circ} \mathrm{C} / \mathrm{km}$ (Velde and Iijima, 1988; Hansen and Lindgreen, 1989). Data from active continental geothermal fields provide the best match for the results at Site 808. Among other things, the geothermal sites prove that $\mathrm{I} / \mathrm{S}$ reactions can move to completion in sediments that are only 1 to $2 \mathrm{Ma}$ in age, but the temper- atures required for $\mathrm{R}=1$ ordering under these circumstances are between $135^{\circ}$ and $155^{\circ} \mathrm{C}$ (Jennings and Thompson, 1986; Walker and Thompson, 1990). It seems likely that peak temperatures in the Shikoku Basin hemipelagic facies were attained within the last 0.5 m.y. (i.e., after the rapid deposition of the overlying Nankai turbidite wedge). Thus, formation of ordered I/S clays probably has been retarded somewhat by insufficient heating times at Site 808 , at least as compared to older stratigraphic examples with much longer burial histories.

Two of the more important aspects of the smectite-to-illite transformation involve the release of interlayer water into the pore system of the host mudrock and the corresponding development of excess pore-fluid pressures if the liberated water cannot dissipate (Burst, 1969; Bruce, 1984; Colten-Bradley, 1987; Freed and Peacor, 1989a; Vrolijk, 1990). In the case of the Nankai accretionary prism, we know that the depth interval containing I/S clays coincides with a decrease in chlorinity values for interstitial fluids (Shipboard Scientific Party, 1991 b; Kastner et al., this volume). Chloride values begin to decrease from maxima of approximately $590 \mathrm{mM}$ at $560-580 \mathrm{mbsf}$ to minima of $450 \mathrm{mM}$ at $1040-1080 \mathrm{mbsf}$. Over this same depth interval, $\mathrm{H}_{4} \mathrm{SiO}_{4}$ concentrations in the interstitial water decrease. Past dissolution of volcanic glass may have removed this reactive component, with vertical migration of pore fluid leading to higher dissolved silica concentrations above Unit IV. Potassium concentrations also decrease sharply in the interstitial waters beginning at a depth of about 400 mbsf (Shipboard Scientific Party, 1991b); this could be caused by potassium uptake by illite interlayers in the mixed-layer clays.

One important question is whether or not the monotonic change in pore-water chlorinity can be attributed to in-situ dehydration of 


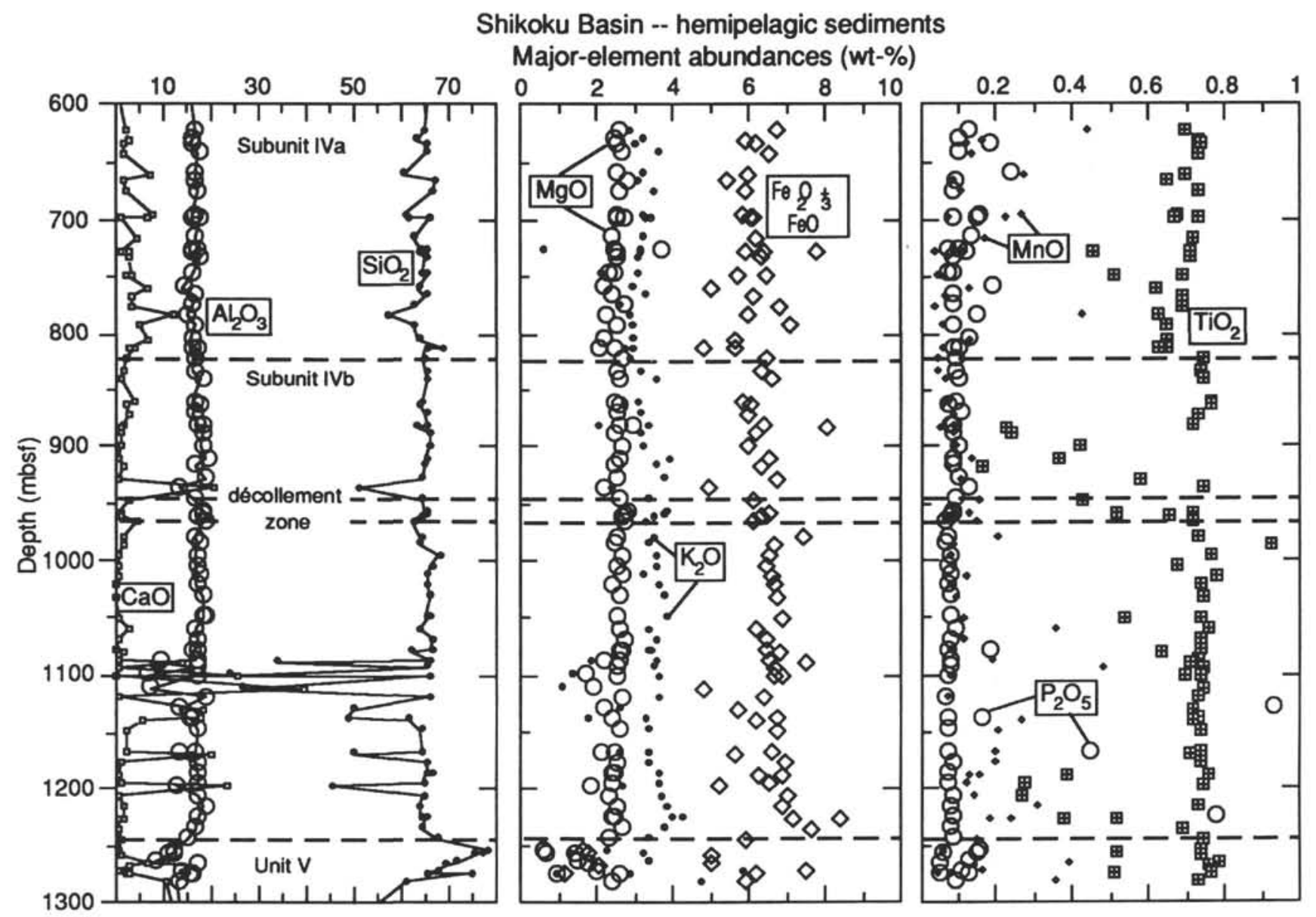

Figure 8. Plots of major-element oxides (wt\%) for Units IV and V at Site 808 (Shikoku Basin deposits). See Pickering et al. (this volume) for a complete listing of data.

smectite, which exists both as a detrital phase and as a replacement product of volcanic glass shards. A related question is whether or not the change in the chlorinity gradient at about $820 \mathrm{mbsf}$ is related to a decrease in the rate at which smectite alters to I/S. We have not completed rigorous mass-balance calculations, but it seems clear from bulk-mud and clay-mineral XRD data that the total amount of smectite in a typical mudstone is not large enough to account for a $25 \%$ dilution of chloride in the interstitial water. Except for the local occurrences of bentonitic layers in Unit IV, the relative percentages of smectite within the clay-mineral population are no higher than about $40 \%$ for the $<2-\mu \mathrm{m}$ size fraction and $25 \%$ for the $2-$ to $6-\mu \mathrm{m}$ size fraction (using Biscaye weighting factors). If the shipboard estimates of total claymineral abundance in the bulk powders are anywhere close to correct, then the typical amount of smectite in the bulk mudstone is less than $10 \%$. If allowances are made for amorphous constituents undetected by XRD (e.g., opaline silica, volcanic glass), then the total nondiagenetic component of expandable clay becomes even lower, probably less than $5 \%$ of the average bulk mudstone.

Vrolijk et al. (1991) summarized the results of mass balance calculations of chloride dilution caused by mixing of fresh interlayer water with saline pore waters, using results from the Barbados accretionary prism to limit some of the boundary conditions. Three variables control this relationship: (1) bulk porosity, (2) percentage of smectite in the total solid fraction, and (3) percentage of the interlayer water expelled from the smectite. Porosity values at Site 808 over the depth interval of 560-1080 mbsf range from $45 \%$ down to $30 \%$ (Shipboard Scientific Party, 1991b). If one assumes a porosity value of $30 \%$, and $50 \%$ expulsion of interlayer water via transformation to a mixed-layer
I/S, then roughly $50 \%$ of the original bulk solid volume must be composed of smectite to lower the chlorinity to $450 \mathrm{mM} / \mathrm{L}$ (Vrolijk et al., 1991). Increasing the expulsion value to $100 \%$ (complete transformation to illite, with loss of both interlayer water and structural water) still requires a bulk smectite concentration of $25 \%$.

Obviously, smectite concentrations are too low and the progression of illitization reactions at Site 808 are not advanced enough to account for the dilution of pore-water chlorinity via in-situ dehydration of clay minerals. Moreover, the alteration of volcanic ash to authigenic smectite and zeolites, particularly within Subunit IVa, should consume substantial amounts of $\mathrm{H}_{2} \mathrm{O}$, perhaps equivalent to $>3 \%$ seawater concentration (Kastner et al., this volume). We acknowledge, therefore, that interstitial seawater has been diluted by fresh water released by smectite dehydration reactions, and that some of the dilution may have occurred in situ, but we also conclude that lower-chlorinity pore water has been imported from other portions of the accretionary prism.

It seems logical to suggest that diluted pore fluids migrated from deeper in the prism, where porosities are lower than $30 \%$. One possible migration pathway is the décollement zone. Evidence for active fluid flow along the décollement is lacking, but an intense transient advective pulse could have injected low $\mathrm{Cl}^{-}$fluid roughly $300,000 \mathrm{yr}$ ago, followed by diffusive downward migration (Kastner et al., this volume). This particular pathway is not necessarily mandated by the data, however. For example, slow movement may have been centered near the horizon of the $\mathrm{Cl}^{-}$concentration minimum, or there could have been mixing between two advective systems, one centered at the $\mathrm{Cl}^{-}$minimum, the other at the $820 \mathrm{mbsf}$ lithologic boundary between Subunits IVa and IVb. This final hypothesis is supported by changes 

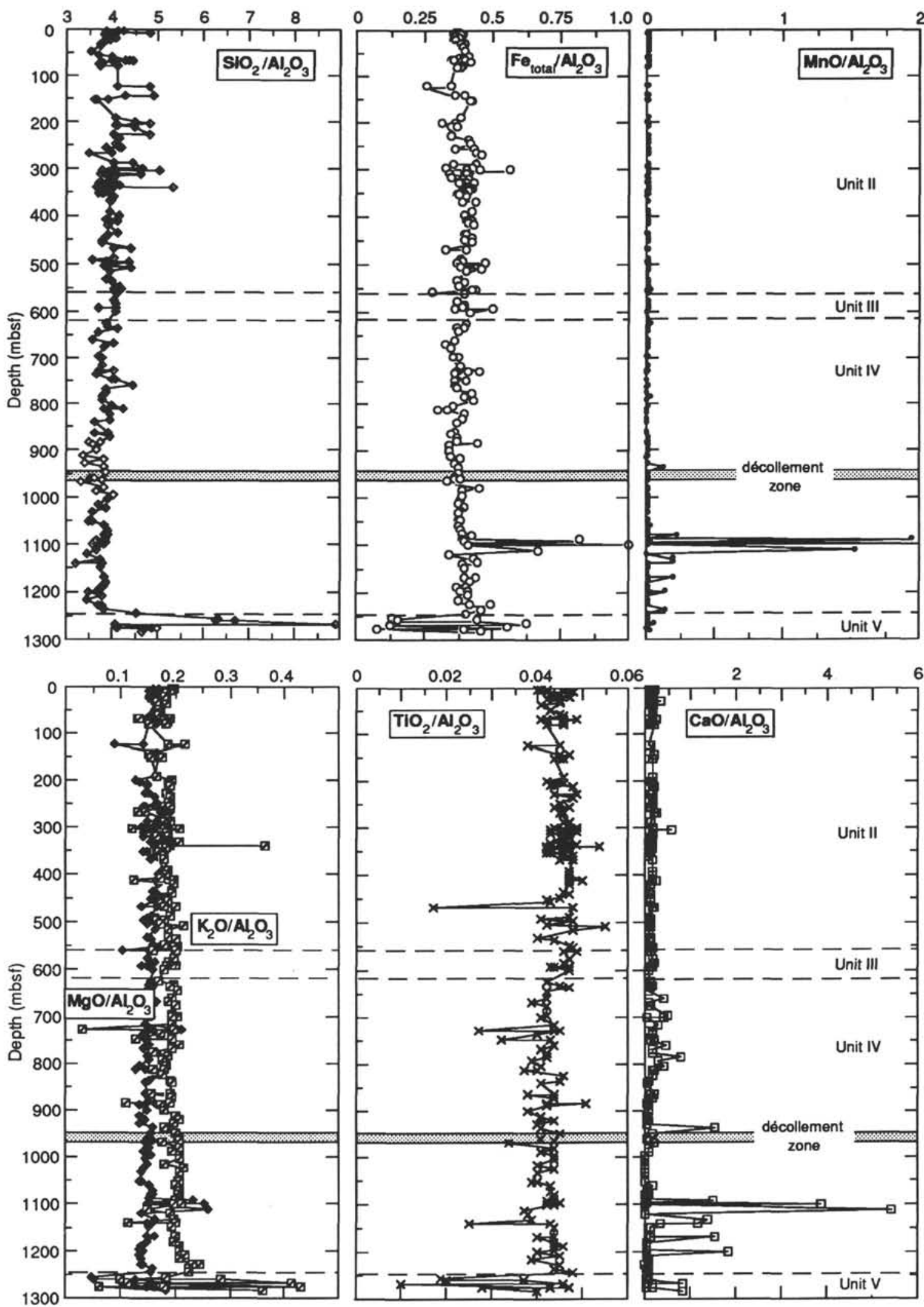

Figure 9. Plots of major-element oxide ratios at Site 808. Fluctuations within Unit $\mathrm{V}$ are related to differences between interbeds of siliceous tuff and hemipelagic mudstone (Fig. 10). The slight gradients in $\mathrm{SiO}_{2} / \mathrm{Al}_{2} \mathrm{O}_{3}$ and $\mathrm{K}_{2} \mathrm{O} / \mathrm{Al}_{2} \mathrm{O}_{3}$ are probably a consequence of volcanic ash alteration and uptake of potassium by illite interlayer in $\mathrm{I} / \mathrm{S}$ clays. Note the sharp increases in $\mathrm{Fe}_{\text {total }} / \mathrm{Al}_{2} \mathrm{O}_{3}, \mathrm{MnO} \mathrm{Al}_{2} \mathrm{O}_{3}$, and $\mathrm{CaO} / \mathrm{Al}_{2} \mathrm{O}_{3}$ in the vicinity of $1100 \mathrm{mbsf}$. See Pickering et al. (this volume) for a complete listing of data. 

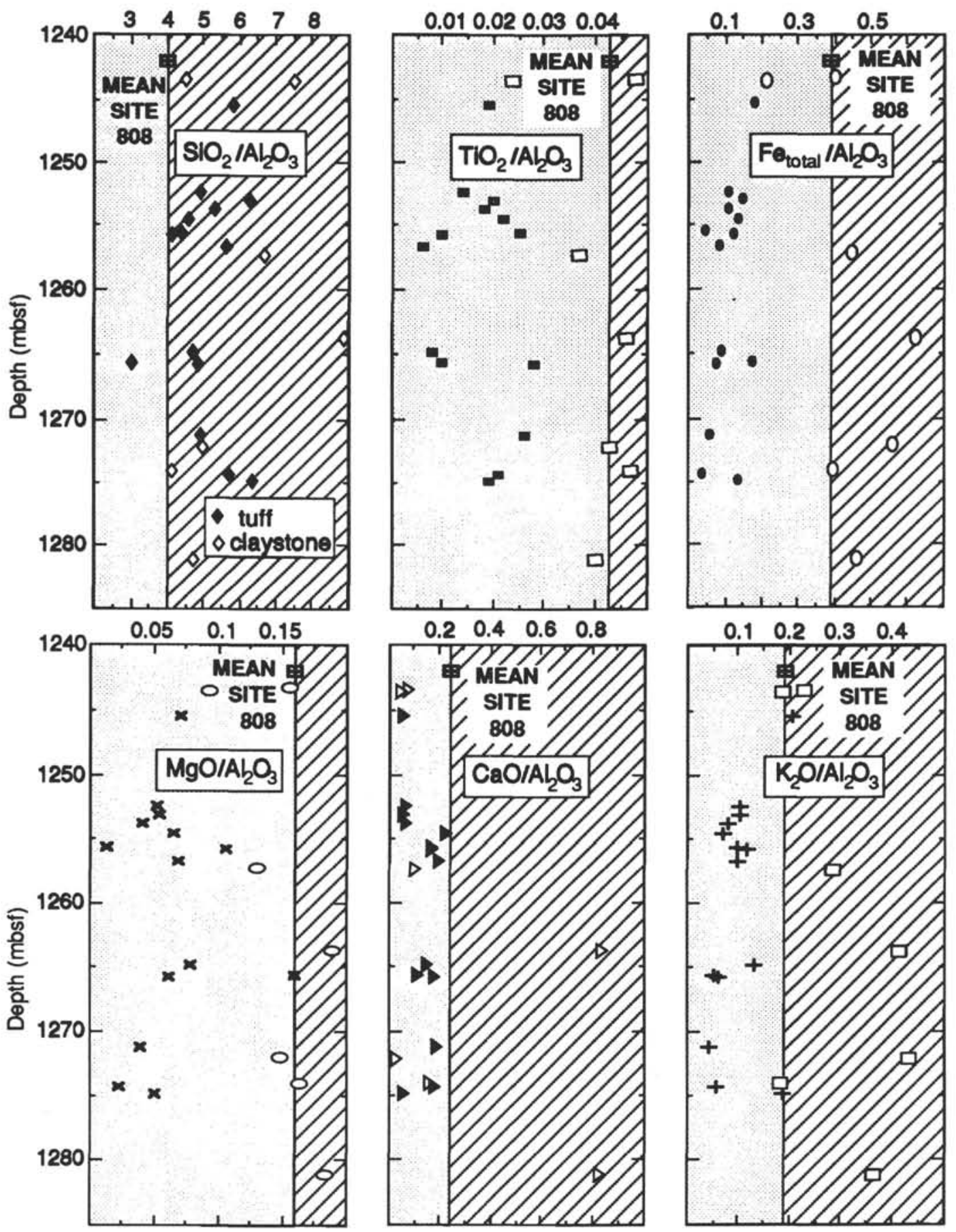

Figure 10. Comparisons among major-element oxide ratios for Unit $\mathrm{V}$ at Site 808. Geochemical domains are plotted relative to average ratios for Site 808. Solid symbols correspond to tuff samples; open symbols denote samples of variegated claystone. See Pickering et al. (this volume) and Masuda et al. (this volume) for complete listings of data.

in ${ }^{18} \mathrm{O}, \mathrm{D}$, and $\mathrm{Sr}$ isotopes across the décollement zone (Kastner et al., this volume). Fluids below the décollement probably were derived from deep-seated portions of the accretionary prism, where underplated mixtures of lower Shikoku Basin mudstones and rhyolitic tuffs have been subjected to advanced stages of illitization.

Only one site was drilled during Leg 131, so we have no means of documenting the possible effects of lateral fluid migration. The documented gradients in borehole temperature and near-surface heat flow certainly are high enough all along the strike of the subduction front to promote widespread smectite dehydration, beginning within the
600- to 1200-mbsf interval of the accretionary prism (Yamano et al., 1984, 1992; Kinoshita and Yamano, 1986; Ashi and Taira, in press). Heat flow decreases systematically with distance toward the shoreline of southwest Japan; this heat-flow gradient depresses the ideal temperature window for illitization deeper into the prism with distance from the deformation front. Without knowing the exact subduction/ accretion trajectories for given parcels of mudstone, it is difficult to predict when or where the ideal temperature conditions for clay-mineral dehydration will be encountered first. The residence time within this temperature window also must be balanced against the effects of 


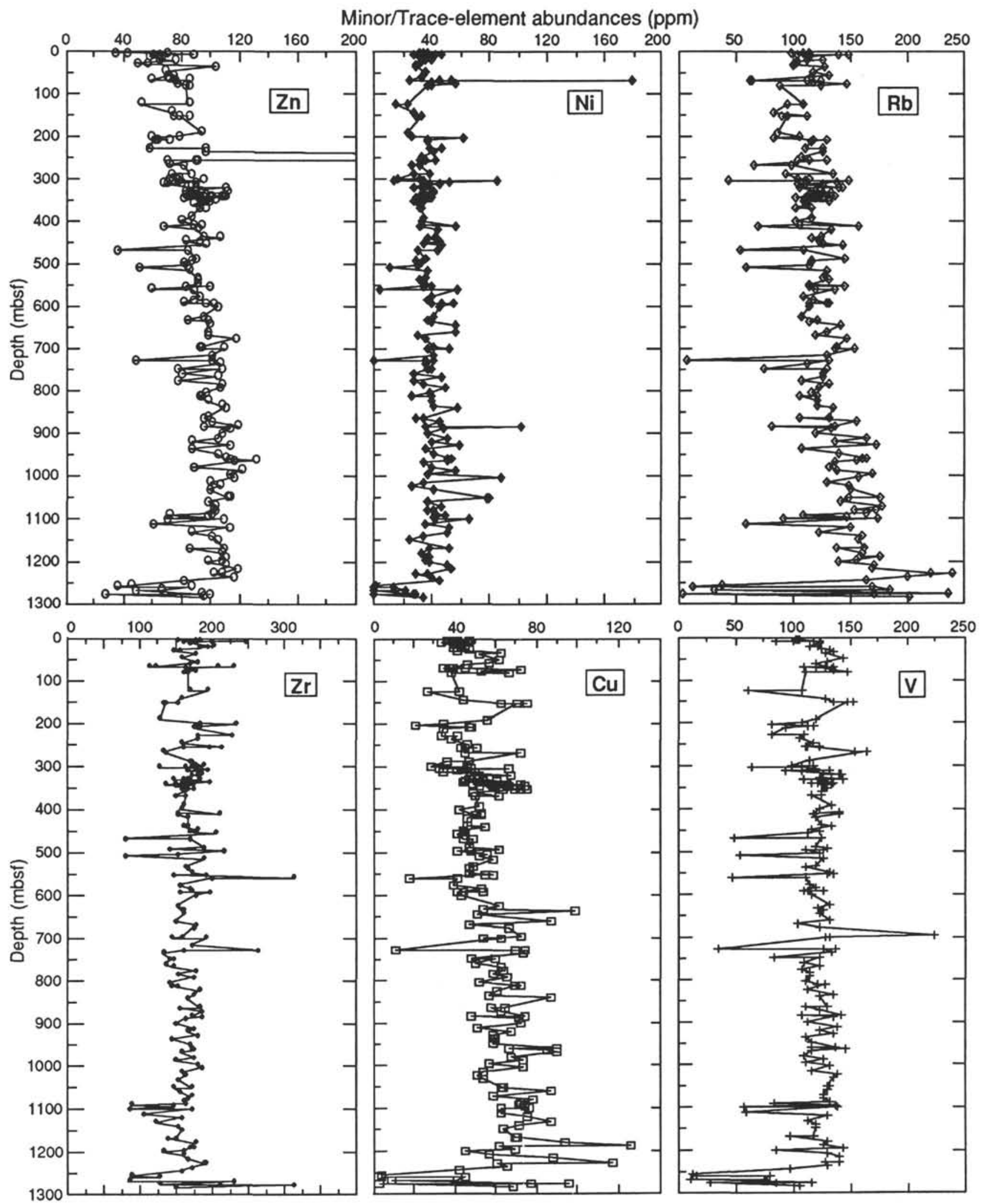

Figure 11. Plots of selected minor- and trace-element abundances (ppm) at Site 808. Note the slight negative gradient in $\mathrm{Zr}$ and the positive gradients in $\mathrm{Zn}, \mathrm{Rb}$, and $\mathrm{Cu}$ as a function of depth. Background concentrations of $\mathrm{Ni}$ and $\mathrm{V}$ are fairly uniform. See Pickering et al. (this volume) for a complete listing of data. 


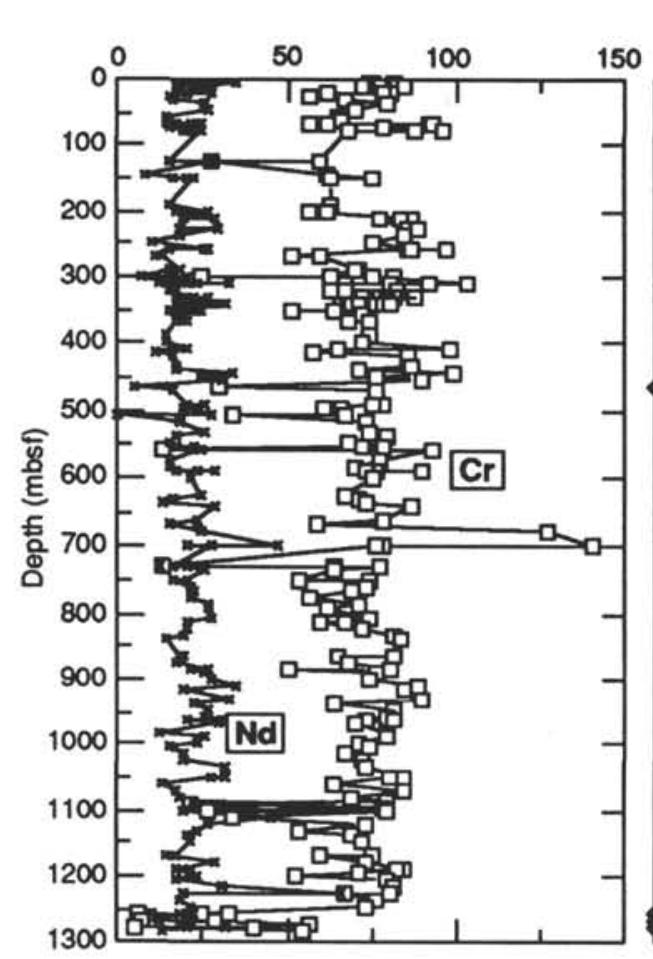

Trace element abundances (ppm)

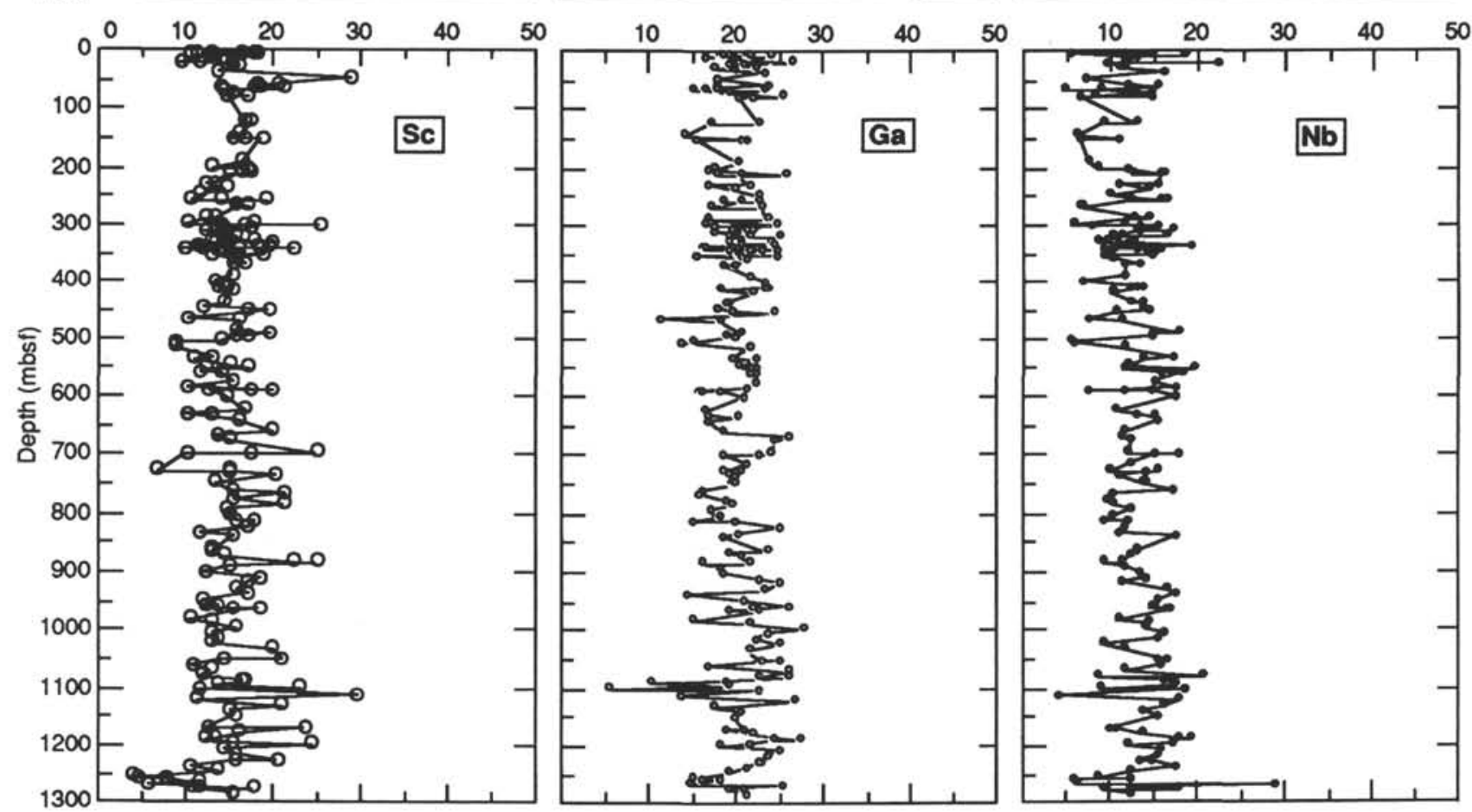

Figure 12. Plots of selected minor- and trace-element abundances $(\mathrm{ppm})$ at Site 808 . These elements do not show any significant variations as a function of depth or lithostratigraphy. See Pickering et al. (this volume) for a complete listing of data.

all kinetic parameters. A unique solution to this problem, therefore, seems unattainable. As an additional complication, clay-mineral data from DSDP sites in the Shikoku Basin suggest that many parts of the abyssal-floor stratigraphy are enriched in smectite relative to the hemipelagic muds at Site 808 (Chamley, 1980). Therefore, the possibility of a lateral component of fluid flux from a comparable zone of high heat flow within the prism toe, but one containing smectite-enriched strata, also should be considered.

\section{Sediment Geochemistry}

\section{Mudstones}

The background data for most geochemical constituents at Site 808 are in agreement with previous analyses of samples from DSDP Sites 297, 582, and 583 (Donnelly, 1980; Kawahata et al., 1986; Minai et al., 1986). Overall, the chemical compositions are remarkably homogeneous throughout the Nankai accretionary prism, with a few 


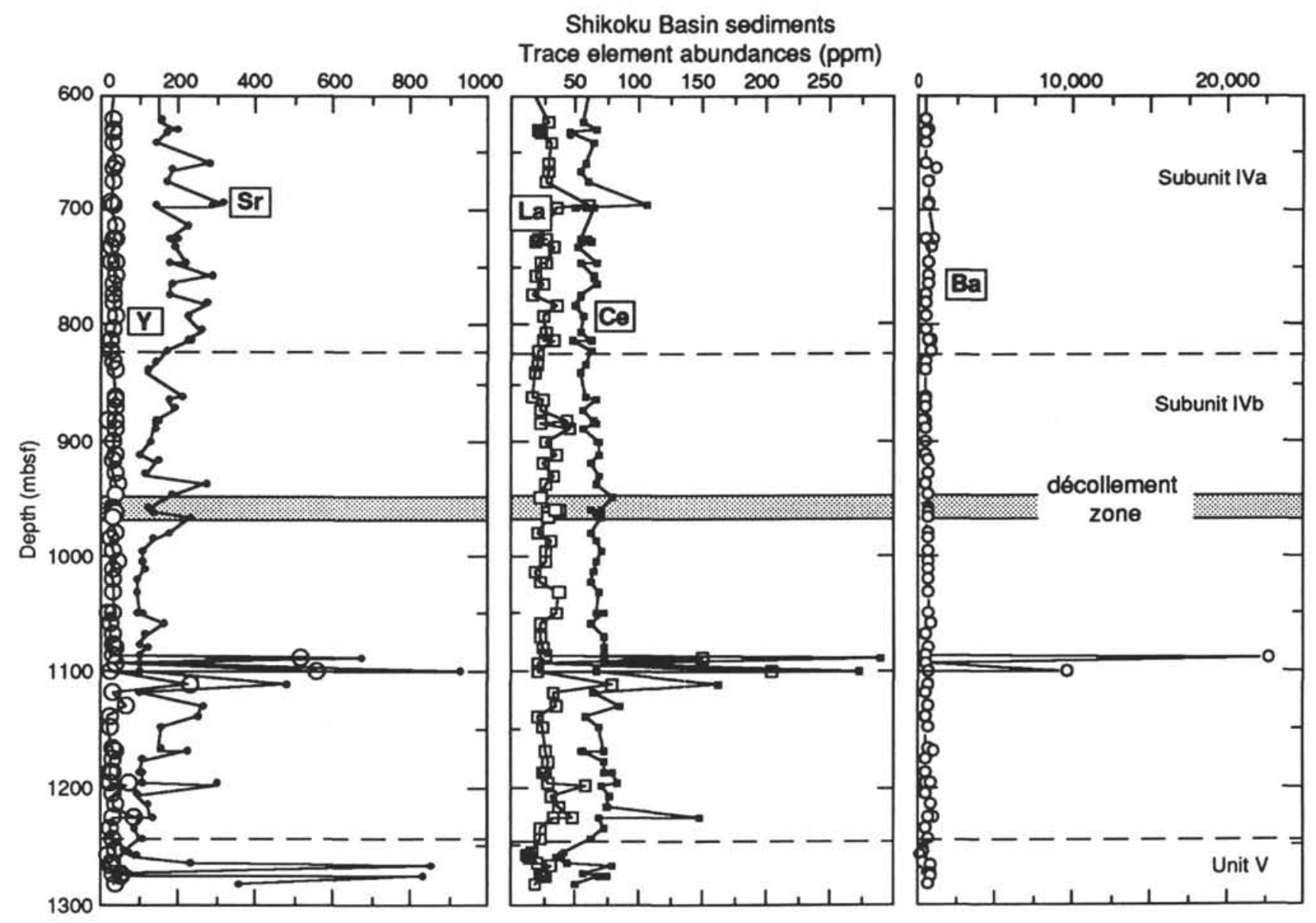

Figure 13. Plots of selected minor- and trace-element abundances (ppm) within Units IV and V at Site 808. Note the anomalous increases in the concentrations of Y, Sr, Ce, Ba, and La near 1100 mbsf. Values within Units I, II, and III are consistent with the results from Subunit IVa. See Pickering et al. (this volume) for a complete listing of data.

exceptions, as discussed below. Most of the minor and trace elements likewise display uniformity through most of the sediment column. The similarities among turbidites of the Nankai trench wedge and underlying hemipelagic mudstones of the Shikoku Basin lead us to conclude that both facies units shared the same basic source of sediment. Within Unit $\mathrm{V}$, however, the ratios of $\mathrm{SiO}_{2} / \mathrm{Al}_{2} \mathrm{O}_{3}, \mathrm{~K}_{2} \mathrm{O}$ / $\mathrm{Al}_{2} \mathrm{O}_{3}$, and $\mathrm{Fe}_{\text {total }} / \mathrm{Al}_{2} \mathrm{O}_{3}$ all increase with respect to the average mudstone at Site 808 (Fig. 10). As discussed in the following section on volcanic ash data, this chemical change is probably a response to differences in the original bulk mud composition rather than in-situ alteration of disseminated volcanic glass.

The silica concentrations for background mudstones at Site 808 typically range from $62 \%$ to $69 \%$. The average $\mathrm{SiO}_{2} / \mathrm{Al}_{2} \mathrm{O}_{3}$ ratio is approximately 4.0 (Fig. 14), and the trench-fill turbidites (Fig. 7) are slightly enriched in $\mathrm{SiO}_{2}$ relative to the mudstones deposited in Shikoku Basin (Fig. 8). These data generally match mudstone compositions from the Leg 31 and Leg 87 drill sites (Fig. 14). Minai et al. (1986) suggested that slight variations in silica concentration at Sites 582 and 583 are due to fluctuations in bulk mineral composition and grain-size distribution. A large component of the total silica budget, particularly within the trench-wedge facies, probably is tied up in silt-sized detrital quartz.

In contrast to the Nankai Trough and Shikoku Basin data, the silica contents of pelagic mudstones located farther to the north in the Japan Trench (Site 584) are significantly higher, reaching weight percentages of $67 \%$ to $88 \%$ (Kawahata et al., 1986; Minai et al., 1986). This $\mathrm{SiO}_{2}$ enrichment in the Japan Trench can be attributed to a substantial increase in the biogenic pelagic constituents (particularly diatoms), combined with a greatly reduced siliciclastic influx from northern Honshu (Coulbourn, 1986).

The $\mathrm{TiO}_{2} / \mathrm{Al}_{2} \mathrm{O}_{3}$ ratio is often cited by sedimentary geochemists as a key to interpretations of detrital mineral provenance, as well as a parameter to characterize the differences between terrigenous and pyroclastic influx. Many terrigenous sediments, for example, have $\mathrm{TiO}_{2} / \mathrm{Al}_{2} \mathrm{O}_{3}$ ratios of about 0.037 (Wang et al., 1990), and the average value for the Pacific Ocean is 0.045 (Boström et al., 1976). Ti/Aloxide ratios within the trench-wedge facies at Site 808 are only slightly lower than this average $(0.043 \pm 0.001)$. Close agreement in $\mathrm{TiO}_{2} / \mathrm{Al}_{2} \mathrm{O}_{3}$ with data from Site 582 (Fig. 14) reinforces the interpretation of a common detrital provenance along the length of the trench wedge (i.e., trends are consistent with $\mathrm{SiO}_{2} / \mathrm{Al}_{2} \mathrm{O}_{3}$ ratios, clay mineralogy, and sand petrography). In addition, lower Ti/Al-oxide ratios ( 0.039) are characteristic of the Unit IV mudstones at Site 808, and there is a clear step-like shift in $\mathrm{TiO}_{2} / \mathrm{Al}_{2} \mathrm{O}_{3}$ at the lithofacies boundary between Unit III and Subunit IVa (Fig. 9). The titanium depletion matches results from the abyssal-plain reference section represented by Shikoku Basin sediments at Site 297. In general, the mean values for Site 808 also agree with data from Sites 442, 443, and 444, which were drilled near the center of Shikoku Basin (Sugisaki, 1980). The largest deviation is in values of $\mathrm{CaO} / \mathrm{Al}_{2} \mathrm{O}_{3}$, which are higher in the basin center due to greater amounts of biogenic pelagic settling.

Chemical effects of sediment diagenesis also are evident, particularly within the Shikoku Basin mudstones of Unit IV. Absolute values of $\mathrm{K}_{2} \mathrm{O}$, for example, increase from about $3 \%$ to $4 \%$ within the lower Shikoku Basin deposits (Fig. 8). There is also a slight positive gradient 

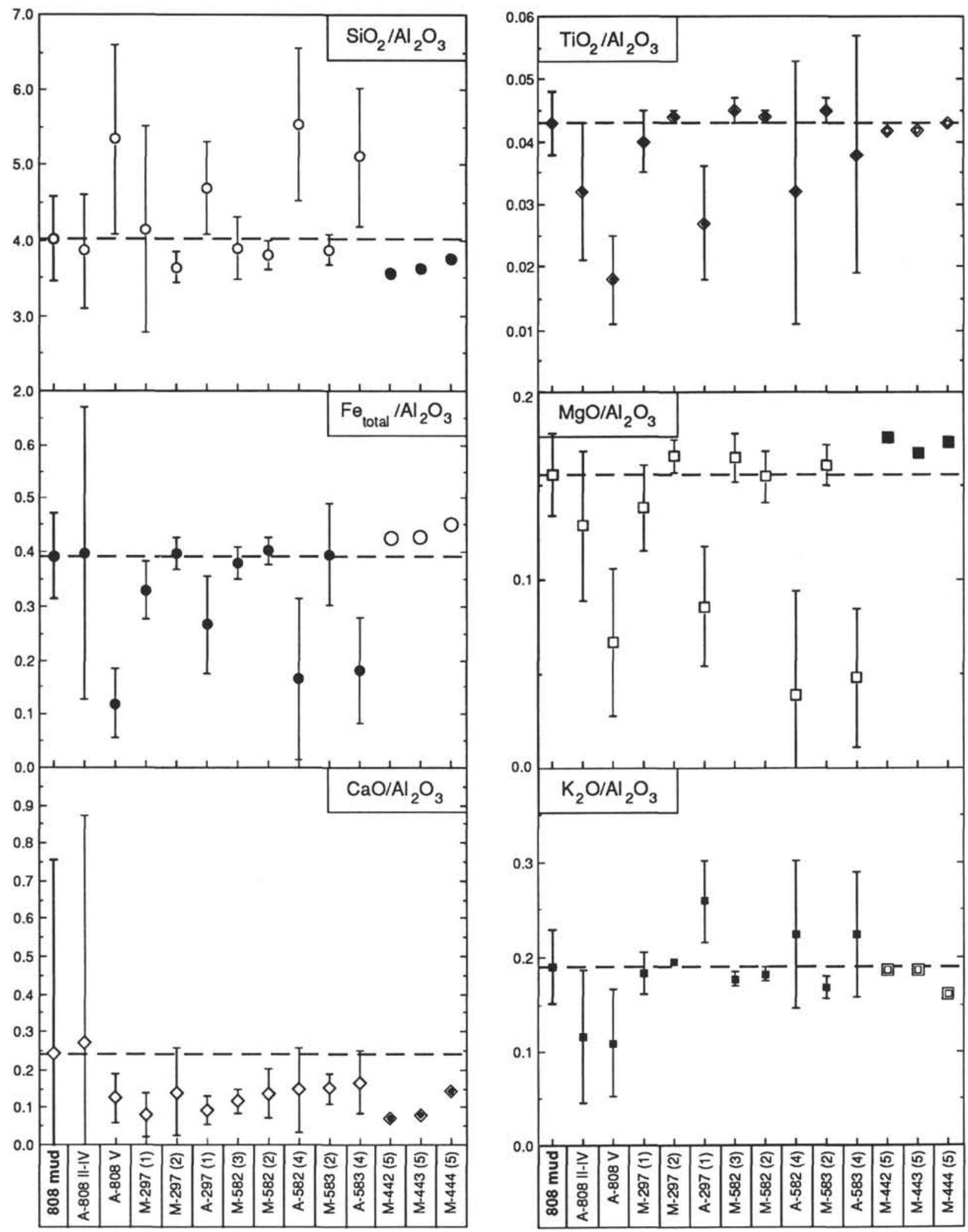

Figure 14. Comparisons among mean values of major-element oxide ratios for mudstones (M) and ash deposits (A) recovered from all DSDP and ODP sites within the Nankai Trough and Shikoku Basin. Bars represent one standard deviation about each mean (s.d. not calculated for Sites 442, 443, or 444). Data for ash deposits within Units II, III, and IV at Site 808 are plotted separately from those of Unit V (see Masuda et al., this volume). Sources of DSDP data (keyed to numbers in parentheses) are: (1) = Donnelly (1980); (2) = Minai et al. (1986); (3) = Kawahata et al. (1986); (4) = Pouclet et al. (1986); and (5) = Sugisaki (1980). 
in the $\mathrm{K}_{2} \mathrm{O} / \mathrm{Al}_{2} \mathrm{O}_{3}$ ratio (Fig. 9), as well as a clear increase in the concentration of $\mathrm{Rb}$ (Fig. 11). These geochemical depth trends match the zone in which dissolved potassium in pore waters decreases to minimum values and the percentage of illite in $\mathrm{I} / \mathrm{S}$ increases from $\sim 20 \%$ to $\sim 60 \%$. We conclude that the chemical changes were caused by uptake of $\mathrm{K}$ and $\mathrm{Rb}$ by authigenic illite.

Some of the remaining chemical variability displayed by strata at Site 808 (as well as among other sites in the region) could be due to small admixtures of volcanic ash in the mudstones. Below, we assess the extent of mixing among siliciclastic and pyroclastic constituents by comparing chemical data from the mudstones directly with data from discrete interbeds of volcanic ash and vitric tuff.

\section{Volcanic Ash Geochemistry}

Chemical analyses of ash deposits at Site 808 (Shipboard Scientific Party, 1991b; Masuda et al., this volume) show significant but erratic departures from the bulk sediment geochemistry. The range of observed $\mathrm{Ti} / \mathrm{Al}$-oxide ratios, for example, is approximately 0.010 to 0.050 , and there is a pronounced decrease in this ratio within the ash-rich intervals of Unit III and Subunit IVa (Fig. 15). Overall, $\mathrm{SiO}_{2}$ contents for ash range from $56 \%$ to $80 \%$, and silica/alumina ratios vary between about 2.5 and 7.5 (Masuda et al., this volume). Between 560 and $820 \mathrm{mbsf}$, ratios of $\mathrm{SiO}_{2} / \mathrm{Al}_{2} \mathrm{O}_{3}, \mathrm{TiO}_{2} / \mathrm{Al}_{2} \mathrm{O}_{3}, \mathrm{MgO} / \mathrm{Al}_{2} \mathrm{O}_{3}$, and $\mathrm{K}_{2} \mathrm{O} / \mathrm{Al}_{2} \mathrm{O}_{3}$ generally decrease in the ash layers, but fluctuations are erratic with respect to the more homogeneous interbeds of mudstone (Fig. 15). The chemical heterogeneity of the pyroclastic material is generally consistent with the documented range of andesitic to rhyolitic sources of explosive volcanism on the Japanese Islands (Masuda et al., this volume). As discussed previously, partial alteration of the glass shards has led to the formation of smectite within discrete ash layers and a depth-dependent increase in the percentage of illite within I/S clays (Shipboard Scientific Party, 1991b; Masuda et al., this volume). However, the chemical effects of the illitization reactions have not produced clearly defined gradients in the bulk ash geochemistry (Fig. 15). Moreover, because of the chemical homogeneity of mudstones throughout most of the Site 808 section (Fig. 15), there is little chemical evidence to support the idea of mixing abundant pyroclastic debris into hemipelagites within Unit III and Subunit IVa.

In contrast to the heterogeneous ash deposits of Unit III and Subunit IVa, all but one of the tuff beds within Unit V are highly siliceous, with most samples containing between $72 \%$ and $80 \%$ silica (Pickering et al., this volume; Masuda et al., this volume). $\mathrm{SiO}_{2} / \mathrm{Al}_{2} \mathrm{O}_{3}$ ratios are consistently greater than the average bulk mudstone from Site 808 , and values are as high as 8.8 (Fig. 10). There is also a pronounced chemical divergence between Unit $\mathrm{V}$ claystones and tuffs, which suggests that the multicolored siliciclastic interbeds contain little disseminated ash. The tuff layers are depleted in $\mathrm{TiO}_{2}$, $\mathrm{Fe}_{\text {total }}, \mathrm{MgO}$, and $\mathrm{K}_{2} \mathrm{O}$ relative to the claystone (Fig. 10). In addition, chemical compositions are more uniform than those of ash deposits in Unit III and Subunit IVa (Figs. 10 and 15). This chemical uniformity indicates that the Miocene pyroclastic eruptions probably emanated from a single rhyolitic source.

Geochemical data from DSDP Leg 31 and Leg 87 sites likewise illustrate the diversity of ash transported into the Nankai Trough and Shikoku Basin. For example, data from Site 297 (Donnelly, 1980) show a consistent increase in $\mathrm{K}_{2} \mathrm{O} / \mathrm{Al}_{2} \mathrm{O}_{3}$ for ash layers relative to the background hemipelagic mud (Fig. 14). The $\mathrm{K}_{2} \mathrm{O} / \mathrm{Al}_{2} \mathrm{O}_{3}$ ratios for most of the ash layers at Site 808 , in contrast, show consistent decreases with respect to the mudstone interbeds (Fig. 15). In addition, the ash at Site 297 contains consistently lower $\mathrm{Fe}_{\text {total }} / \mathrm{Al}_{2} \mathrm{O}_{3}$, $\mathrm{TiO}_{2} / \mathrm{Al}_{2} \mathrm{O}_{3}$, and $\mathrm{MgO} / \mathrm{Al}_{2} \mathrm{O}_{3}$ ratios and higher $\mathrm{SiO}_{2} / \mathrm{Al}_{2} \mathrm{O}_{3}$ ratios (relative to the host mudstones), whereas the same oxide ratios are much more erratic with respect to the mudstone background at Site 808. Chemical data are sparse for Site 297, so it is not clear how much of the disparity is due to ash alteration with depth, as opposed to chemical differences in the volcanic sources that supplied Sites 297 and 808 , respectively. Chemical analyses of volcanic glass from Sites 582 and 583 (Pouclet et al., 1986) add to the complexity. These ash layers also yield consistently higher silica contents than the background mudstones (Fig. 14). Most of that glass is dacitic to rhyolitic in composition $\left(\mathrm{SiO}_{2}=69 \%\right.$ to $\left.74 \%\right)$, with medium values of $\mathrm{K}_{2} \mathrm{O}$ ( $2.3 \%$ to $4.1 \%)$ and relatively low values of $\mathrm{Al}_{2} \mathrm{O}_{3}$ (11.1\% to $15.1 \%$ ). Thus, even though the chemical compositions of the dominant mudstone lithologies are quite uniform throughout the Nankai-Shikoku depositional system, the volcanic glass component clearly has been derived from multiple sources.

We agree with the assessment of Pouclet et al. (1986), who identified the principal pyroclastic source as the Quaternary volcanic arc of southwest Japan, including the Izu-Honshu collision zone (Fig. 1). A second likely source is associated with explosive volcanic centers on Kyushu. Rhyolitic eruptions during the middle Miocene (Unit V at Site 808) were unique; they probably were related to a widespread phase of near-trench magmatism, as preserved within the Shimanto Belt and related units of the Outer Zone of southwest Japan (e.g., Oba, 1977; Shibata and Ishihara, 1979; Terakado et al., 1988; Hibbard and Karig, 1990). It may be that some of the Miocene eruptions occurred within the submerged accretionary prism, thereby triggering subaqueous pyroclastic surges and high-concentration turbidity currents that moved into the Shikoku Basin well seaward of the paleo-subduction front.

\section{Hydrothermal Anomaly}

Perhaps the most enigmatic result from chemical analyses of the bulk mudstones at Site 808 is the zone of anomalous elemental concentrations between 1087 and 1111 mbsf. Samples within this interval yield vastly elevated ratios of $\mathrm{CaO} / \mathrm{Al}_{2} \mathrm{O}_{3}, \mathrm{MgO} / \mathrm{Al}_{2} \mathrm{O}_{3}$, $\mathrm{Fe}_{\text {total }} / \mathrm{Al}_{2} \mathrm{O}_{3}$, and $\mathrm{MnO} / \mathrm{Al}_{2} \mathrm{O}_{3}$, and there are smaller positive anomalies (particularly $\mathrm{CaO}$ and $\mathrm{MnO}$ ) that extend down to depths of around 1200 mbsf (Fig. 9). The ratios $\mathrm{SiO}_{2} / \mathrm{Al}_{2} \mathrm{O}_{3}$ and $\mathrm{TiO}_{2} / \mathrm{Al}_{2} \mathrm{O}_{3}$ do not change appreciably over this interval, which suggests that the chemical signature is not related to detrital or pyroclastic influx. In addition, three samples between 1087 and 1111 mbsf have large increases in the concentration of $\mathrm{Ba}, \mathrm{Y}, \mathrm{La}, \mathrm{Ce}$, and $\mathrm{Sr}$ (Fig. 13).

The anomalous zone near 1100 mbsf probably was caused by chemical precipitates from a hydrothermal fluid, though perhaps at a relatively low temperature. In support of this idea, we note that patches of diagenetic carbonate (including siderite) were detected during the shipboard core descriptions (Shipboard Scientific Party, $1991 \mathrm{~b}$ ), and this material could contain appreciable quantities of $\mathrm{Mn}$ (up to $50 \mathrm{~mol} \%$ ), $\mathrm{Mg}(3-8 \mathrm{~mol} \%), \mathrm{Sr}$, and Fe. Preliminary mineralogic analyses also indicate the presence of apatite, rhodochrosite, barite, pyrite, anatase, and rutile within this zone (Kastner et al., this volume). We believe that a detailed program of X-ray diffraction and chemical analyses, with a much closer sample spacing and focused targets, must be completed before the absolute chemical contributions of $\mathrm{Ca}$-bearing and $\mathrm{Fe}$-bearing carbonates, barite, and the other minerals can be quantified.

We also have no means of determining when the inferred hydrothermal anomaly was imposed on the mudstones of Subunit IVb. One possibility would be during the early stages of sedimentation above newly formed lithosphere of Shikoku Basin. The stratigraphic interval in question contains nannofossils that are 11.1 to $12.2 \mathrm{Ma}$ in age (Shipboard Scientific Party, 1991b). According to Chamot-Rooke et al. (1987), the central region of Shikoku Basin experienced a final phase of highly disorganized volcanic activity between 15 and $12 \mathrm{Ma}$. Thus, the sediments could share some of the characteristics of ophiolite-related umbers (e.g., Robertson and Hudson, 1974), which are broadly analogous to the metalliferous sediments associated with hydrothermal circulation at many mid-ocean spreading centers (e.g., Bonatti, 1975). It is important to note, however, that we uncovered no evidence of chemical gradients towards the basaltic basement at Site 808 , as might be expected with simple vertical movement within 

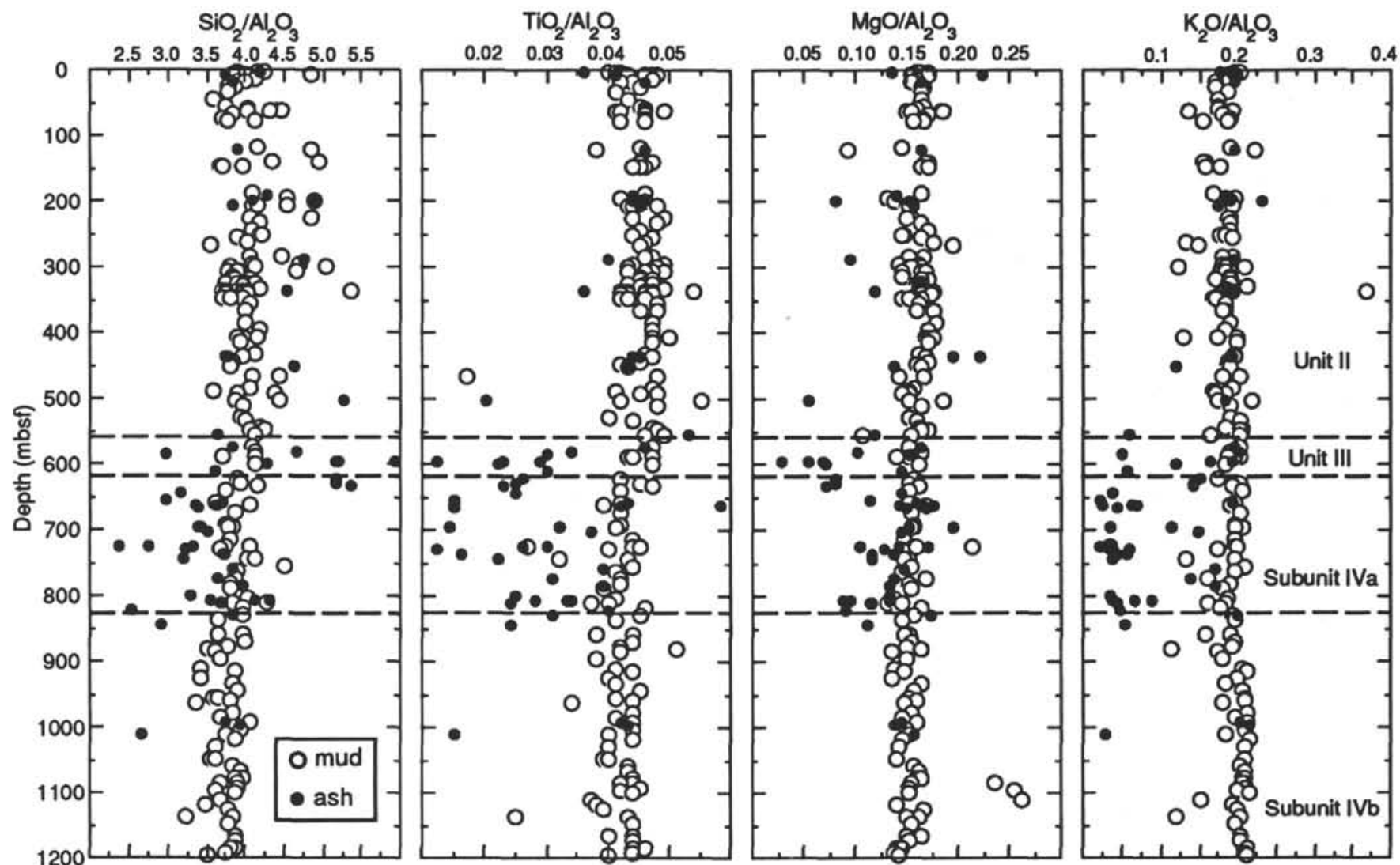

Figure 15. Comparisons among major-element oxide ratios for mudstones (open circles) and interbedded ash layers (solid dots) at Site 808. Results from Unit V are shown in Figure 10. See Pickering et al. (this volume) and Masuda et al. (this volume) for complete listings of data. Note the irregular geochemical divergence as a function of lithology.

a hydrothermal convection cell (e.g., Drever, 1976). Therefore, we suggest that lateral injection of warm fluid early in the depositional history of Shikoku Basin provides a better explanation. Alternatively, the chemical precipitates may have formed very recently. According to this third hypothesis, the acquired geochemical signal would be related to advection of fluids from greater depths in the accretionary prism. Shipboard measurements of physical properties do show erratic values of porosity and water content in the vicinity of $1100 \mathrm{mbsf}$ (Shipboard Scientific Party, 1991b), but why fluids enriched in $\mathrm{Ca}$, $\mathrm{Mn}, \mathrm{Mg}$, and $\mathrm{Fe}$ (plus $\mathrm{Y}, \mathrm{Ba}, \mathrm{Sr}, \mathrm{La}$, and $\mathrm{Ce}$ ) would become focused in this relatively narrow interval remains unknown. Additional laboratory research obviously is needed to provide adequate tests of these provisional ideas.

\section{CONCLUSIONS}

Preliminary interpretations of the clay-mineralogy data from Site 808 , together with the results of bulk-mudstone geochemical analyses, have led to the following conclusions:

1. The relative percentages of the principal clay minerals do not change significantly within the turbidite wedge of the Nankai Trough (Unit II). Illite is the most abundant detrital clay mineral, followed successively by chlorite, smectite, and kaolinite. The same basic detrital assemblage is also characteristic of the underlying hemipelagic deposits of the Shikoku Basin. There are no deviations in clay mineralogy within the décollement zone.

2. There is a monotonic increase in smectite content within the upper Shikoku Basin facies (Subunit IVa). This enrichment of expandable clays can be attributed, in part, to diagenetic alteration of disseminated volcanic ash, and the increase starts at a depth of approximately $560 \mathrm{mbsf}$ (Unit III). Smectite begins to decrease relative to other clay minerals at a depth of $820 \mathrm{mbsf}$, probably for two reasons. First, there were lesser amounts of detrital smectite, disseminated glass shards, and discrete layers of ash deposited in the lower Shikoku Basin facies (Subunit IVb). Second, burial temperatures within this part of the accretionary prism have reached high enough levels within the past $0.5 \mathrm{~m} . \mathrm{y}$. to promote the transformation of smectite to illite.

3. There is a regular increase in the illite content of $\mathrm{I} / \mathrm{S}$ within Units III and IV. The initial appearance of diagenetic I/S occurs at a depth of approximately $555 \mathrm{mbsf}$. If linear extrapolation of the shallow geothermal gradient is valid to this depth, then the presentday temperature associated with the initial formation of random $(\mathrm{R}=0) \mathrm{I} / \mathrm{S}$ interstratification is $\sim 65^{\circ} \mathrm{C} . \mathrm{R}=1$ ordering in the $<2-\mu \mathrm{m}$ size fraction first occurs at a depth of 1220 mbsf and a temperature of $\sim 135^{\circ} \mathrm{C}$. Within the $<0.2-\mu \mathrm{m}$ size fraction, $\mathrm{R}=1$ ordering first appears at a depth of $1060 \mathrm{mbsf}$ and a temperature of $\sim 120^{\circ} \mathrm{C}$. These results are consistent with data from other sedimentary basins, particularly those where geothermal gradients are abnormally high (i.e., active geothermal fields).

4. The progressive increase in illite interlayers in I/S mixed-layer clays occurs over the same depth interval as a documented reduction in pore-water chlorinity. However, the absolute abundance of smectite in the Shikoku Basin section at Site 808 (Unit IV) appears to be much too small to generate the necessary volume of fresh water entirely through in-situ smectite dehydration. Therefore, low-chlorinity pore waters probably migrated to Site 808 from another source. We believe that the most likely sources are located deeper in the accretionary prism, where lower porosities and/or higher smectite percentages would promote greater amounts of pore-water dilution during smectite dehydration. Alternatively, some lateral migration may have occurred 
within the prism toe from pockets of Shikoku Basin mudstone containing greater percentages of detrital and/or authigenic smectite.

5. Overall, the hemipelagic mudstones at Site 808 display uniform chemical compositions, and this trend is consistent with the relatively homogeneous mineralogies detected through X-ray diffraction. There are no anomalies in major elements, minor elements, or trace elements for mudstones recovered from the décollement zone. The geochemical data, therefore, reinforce our analyses and interpretations of the relative clay mineral percentages, which change only slightly down-section. A slight increase in $\mathrm{K}_{2} \mathrm{O}$ and $\mathrm{Rb}$ within the Shikoku Basin facies is probably due to uptake of those cations by illite layers in $\mathrm{I} / \mathrm{S}$ clays.

6. Comparisons of bulk mudstone compositions with data from layers of volcanic ash at Site 808 (plus ash layers from DSDP Sites 297, 582 , and 583) show that the pyroclastic material has been transported into the Nankai trench wedge and the Shikoku Basin from a variety of andesitic to rhyolitic sources. For the most part, however, dissemination of ash into the background mud deposits has not resulted in significant departures from the average bulk mudstone geochemistry. Geochemical divergence is particularly pronounced between interbedded rhyolitic tuffs and variegated claystones of Unit V, which formed during incipient stages of sedimentation above the basaltic basement. We correlate the Unit V tuffs with silicic magmatic bodies throughout the Outer Zone of southwest Japan, and speculate that some of the anomalous near-trench eruptions may have been subaqueous.

7. The only dramatic geochemical anomaly at Site 808 occurs between 1087 and 1111 mbsf, where we discovered sharp increases in $\mathrm{CaO} / \mathrm{Al}_{2} \mathrm{O}_{3}, \mathrm{MgO} / \mathrm{Al}_{2} \mathrm{O}_{3}, \mathrm{Fe}_{\text {total }} / \mathrm{Al}_{2} \mathrm{O}_{3}$, and $\mathrm{MnO} / \mathrm{Al}_{2} \mathrm{O}_{3}$ ratios, together with abnormally high concentrations of $\mathrm{Ba}, \mathrm{Y}, \mathrm{La}, \mathrm{Ce}$, and $\mathrm{Sr}$. This anomalous zone is probably related to precipitation of $\mathrm{Ca}$ - and $\mathrm{Fe}$-carbonates, barite, and other minerals from hydrothermal fluids, but we are uncertain as to the timing of the event. One possibility would be early in the depositional history of Shikoku Basin, as umbers formed above juvenile oceanic crust; the alternative explanation would be during Holocene migration of fluids originating from deep within the Nankai accretionary prism.

\section{ACKNOWLEDGMENTS}

We appreciate the crew and staff aboard the JOIDES Resolution for their assistance during sample acquisition. XRF analyses were completed by N. Marsh and B. Dickie and funded by the Department of Geology at the University of Leicester. E. Hathon and D. Bergfeld assisted with XRD analyses at the University of Missouri, and funding was provided by the National Science Foundation through the Joint Oceanographic Institutions, U.S. Science Support Program. We thank Peter Vrolijk, R.C. Reynolds, and D.R. Pevear for their reviews of the manuscript.

\section{REFERENCES ${ }^{*}$}

Ashi, J., and Taira, A., in press. Thermal structure of the Nankai accretionary prism as inferred from the distribution of gas hydrate BSRs. In Underwood, M.B. (Ed.), Thermal Evolution of the Tertiary Shimanto Belt, Southwest Japan: An Example of Ridge-trench Interaction. Spec. Pap.-Geol. Soc. Am.

Bethke, C.M., and Altaner, S.P., 1986. Layer-by-layer mechanism of smectite illitization and application to a new rate law. Clays Clay Miner, 34:136-145.

Bethke, C.M., Vergo, N., and Altaner, S.P., 1986. Pathways of smectite illitization. Clays Clay Miner., 34:125-135.

Biscaye, P.E., 1965. Mineralogy and sedimentation of recent deep-sea clays in the Atlantic Ocean and adjacent seas and oceans. Geol. Soc. Am. Bull., 76:803-832.

Bonatti, E., 1975. Metallogenesis at oceanic spreading centers. Annu. Rev. Earth Planet. Sci., 3:401-431.

Boström, K., Joensuu, O., Valdés, S., Charm, W., and Glaccum, R., 1976. Geochemistry and origin of East Pacific sediments sampled during DSDP

* Abbreviations for names of organizations and publications in ODP reference lists follow the style given in Chemical Abstracts Service Source Index (published by American Chemical Society).
Leg 34. In Yeats, R.S., Hart, S.R., et al., Init. Repts. DSDP, 34: Washington (U.S. Govt. Printing Office), 556-574.

Bruce, C.H., 1984. Smectite dehydration-its relation to structural development and hydrocarbon accumulation in northern Gulf of Mexico basin. AAPG Bull., 68:673-683.

Burst, J.F., 1969. Diagenesis of Gulf Coast clayey sediments and its possible relation to petroleum migration. AAPG Bull., 53:73-93.

Chamley, H., 1980. Clay sedimentation and paleoenvironment in the Shikoku Basin since the middle Miocene (Deep Sea Drilling Project Leg 58, North Philippine Sea). In Klein, G.deV., Kobayashi, K., et al., Init. Repts. DSDP, 58: Washington (U.S. Govt. Printing Office), 669-678.

Chamley, H., Cadet, J.-P., and Charvet, J., 1986. Nankai Trough and Japan Trench Late Cenozoic paleoenvironments deduced from clay mineralogic data. In Kagami, H., Karig, D.E., Coulbourn, W.T., et al., Init. Repts. DSDP, 87: Washington (U.S. Govt. Printing Office), 633-641.

Chamot-Rooke, N., Renard, V., and Le Pichon, X., 1987. Magnetic anomalies in the Shikoku Basin: a new interpretation. Earth Planet. Sci. Lett., 83:214-228.

Colten-Bradley, V.A., 1987. Role of pressure in smectite dehydration effects on geopressure and smectite-to-illite transformation. AAPG Bull., 71:1414-1427.

Cook, H.E., Zemmels, I., and Matti, J.C., 1975. X-ray mineralogy data, far western Pacific, Leg 31 Deep Sea Drilling Project. In Karig, D.E., Ingle, J.C., Jr., et al., Init. Repts. DSDP, 31: Washington (U.S. Govt. Printing Office), 883-895.

Coulbourn, W.T., 1986. Sedimentologic summary, Nankai Trough Sites 582 and 583, and Japan Trench Site 584. In Kagami, H., Karig, D.E., Coulbourn, W.T., et al., Init. Repts. DSDP, 87: Washington (U.S. Govt. Printing Office), 909-926.

Donnelly, T.W., 1980. Chemical composition of deep sea sediments-Sites 9 through 425, Legs 2 through 54, DSDP. In Rosendahl, B.R., Hekinian, R., et al., Init. Repts. DSDP, 54: Washington (U.S. Govt. Printing Office), 899-949.

Drever, J.I., 1976. Chemical and mineralogical studies, Site 323. In Hollister, C.D., Craddock, C., et al., Init. Repts. DSDP, 35: Washington (U.S. Govt. Printing Office), $471-477$

Dypvik, H., 1983. Clay mineral transformations in Tertiary and Mesozoic sediments from North Sea. AAPG Bull., 67:160-165.

Eberl, D., and Hower, J., 1976. Kinetics of illite formation. Geol. Soc. Am. Bull., 87:1326-1330.

Eberl, D., and Hower, J., 1977. The hydrothermal transformation of sodium and potassium smectite into mixed-layer clay. Clays Clay Miner, 25:215-227.

Eberl, D.D., 1978. The reaction of montmorillonite to mixed-layer clay: the effect of interlayer alkali and alkaline earth cations. Geochim. Cosmochim. Acta, 42:1-7.

Freed, R.L., and Peacor, D.R., 1989a. Geopressured shale and sealing effect of smectite to illite transition. AAPG Bull., 73:1223-1232.

, 1989b. Variability in temperature of the smectite/illite reaction in Gulf Coast sediments. Clay Miner., 24:171-180.

Hansen, P.L., and Lindgreen, H., 1989. Mixed-layer illite/smectite diagenesis in Upper Jurassic claystones from the North Sea and onshore Denmark. Clay Miner., 24:197-213.

Hathon, E.G., 1992. X-ray diffraction and transmission electron microscopy study of the surface charge on the illite and smectite components of illite/ smectite mixed-layer clays [Ph.D. dissert.]. Univ. of Missouri, Columbia.

Hibbard, J.P., and Karig, D.E., 1990. Alternative plate model for the early Miocene evolution of the southwest Japan margin. Geology, 18:170-174.

Hower, J., Eslinger, E.V., Hower, M.E., and Perry, E.A., 1976. Mechanism of burial metamorphism of argillaceous sediment: 1. mineralogical and chemical evidence. Geol. Soc. Am. Bull., 87:725-737.

Inoue, A., Bouchet, A., Velde, B., and Meunier, A., 1989. Convenient technique for estimating smectite layer percentage in randomly interstratified illite/smectite minerals. Clays Clay Miner., 37:227-234.

Jennings, S., and Thompson, G.R., 1986. Diagenesis of Plio-Pleistocene sediments of the Colorado River Delta, southern California. J. Sediment. Petrol., 56:89-98.

Kawahata, H., Fujioka, K., and Ishizuka, T., 1986. Sediments and interstitial water at Sites 582 and 584, the Nankai Trough and the Japan Trench landward slope. In Kagami, H., Karig, D.E., Coulbourn, W.C., et al., Init. Repts. DSDP, 87: Washington (U.S. Govt. Printing Office), 865-875.

Kinoshita, H., and Yamano, M., 1986. The heat flow anomaly in the Nankai Trough area. In Kagami, H., Karig, D.E., Coulbourn, W.T., et al., Init. Repts. DSDP, 87: Washington (U.S. Govt. Printing Office), 737-743.

Le Pichon, X., Iiyama, T., Chamley, H., Charvet, J., Faure, M., Fujimoto, H., Furuta, T., Ida, Y., Kagami, H., Lallemant, S., Leggett, J., Murata, A., Okada, 
H., Rangin, C., Renard, V., Taira, A., and Tokuyama, H., 1987. Nankai Trough and the fossil Shikoku Ridge: results of Box 6 Kaiko survey. Earth Planet. Sci. Lett., 83:186-198.

Lister, C.R.B., 1977. Estimates for heat flow and deep rock properties based on boundary layer theory. Tectonophysics, 41:157-171.

Minai, Y., Matsumoto, R., and Tominaga, T., 1986. Geochemistry of the deep sea sediments from the Nankai Trough, the Japan Trench, and adjacent regions. In Kagami, H., Karig, D.E., and Coulbourn, W.T., et al., Init. Repts. DSDP, 87: Washington (U.S. Govt. Printing Office), 643-657.

Moore, D.M., and Reynolds, R.C., Jr., 1989. X-ray Diffraction and the Identification and Analysis of Clay Minerals: Oxford (Oxford Univ. Press).

Moore, G.F., Shipley, T.H., Stoffa, P.L., Karig, D.E., Taira, A., Kuramoto, S., Tokuyama, H., and Suyehiro, K., 1990. Structure of the Nankai Trough accretionary zone from multichannel seismic reflection data. J. Geophys. Res., 95:8753-8765.

Moore, J.C., 1989. Tectonics and hydrogeology of accretionary prisms: role of the décollement zone. J. Struct. Geol., 11:95-106.

Oba, N., 1977. Emplacement of granitic rocks in the Outer Zone of southwest Japan and geological significance. J. Geol., 85:383-393.

Orr, R.M., 1992. Clay mineralogy, diagenesis, and provenance of sediments in the Nankai Trough, offshore Shikoku Island, southwest Japan [M.S. thesis]. Univ. of Missouri, Columbia.

Parsons, B., and Sclater, J.G., 1977. An analysis of the variation of ocean floor bathymetry and heat flow with age. J. Geophys. Res., 82:803-827.

Perry, E., and Hower, J., 1970. Burial diagenesis in Gulf Coast pelitic sediments. Clays Clay Miner., 18:165-177.

Piper, D.J.W., von Huene, R., and Duncan, J.R., 1973. Late Quaternary sedimentation in the active eastern Aleutian Trench. Geology, 1:19-22.

Pouclet, A., Fujioka, K., Charvet, J., and Cadet, J.-P., 1986. Petrography and geochemistry of volcanic ash layers from Leg 87A, Nankai Trough (South Japan). In Kagami, H., Karig, D.E., Coulbourn, W.T., et al., Init. Repts. DSDP, 87: Washington (U.S. Govt. Printing Office), 695-701.

Pytte, A.M., and Reynolds, R.C., 1989. The thermal transformation of smectite to illite. In Naeser, N.D., and McCulloh, T.H. (Eds.), Thermal History of Sedimentary Basins: New York (Springer-Verlag), 133-140.

Ramseyer, K., and Boles, J.R., 1986. Mixed-layer illite/smectite minerals in Tertiary sandstones and shales, San Joaquin Basin, California. Clays Clay Min., 34:115-124.

Reck, B.H., 1987. Implications of measured thermal gradients for water movement through the northeast Japan accretionary prism. J. Geophys. Res., 92:3683-3690.

Reynolds, R.C., Jr., 1983. Calculation of absolute intensities for mixed-layer clays. Clays Clay Miner., 31:233-234.

Reynolds, R.C., Jr., and Hower, J., 1970. The nature of interlayering in mixed-layer illite-montmorillonites. Clays Clay Miner., 18:25-36.

Roberson, H.E., and Lahann, R.W., 1981. Smectite to illite conversion rates: effects of solution chemistry. Clays Clay Miner., 29:129-135.

Robertson, A.H.F., and Hudson, J.D., 1974. Pelagic sediments in the Cretaceous and Tertiary history of the Troodos Massif, Cyprus. In Hsü, K.J., and Jenkyns, H.C. (Eds.), Pelagic Sediments: On Land and Under the Sea: Spec. Publ. Int. Assoc. Sedimentol., 403-436.

Schoonmaker, J., Mackenzie, F.T., and Speed, R.C., 1986, Tectonic implications of illite/smectite diagenesis, Barbados accretionary prism. Clays Clay Miner, 34:465-472.

Seely, D.R., Vail, P.R., and Walton, G.G., 1974. Trench slope model. In Burk, C.A., and Drake, C.L. (Eds.), The Geology of Continental Margins: Berlin (Springer-Verlag), 249-260.

Shibata, K., and Ishihara, S., 1979. Initial ${ }^{87} \mathrm{Sr} /{ }^{86} \mathrm{Sr}$ ratios of plutonic rocks from Japan. Contrib. Mineral. Petrol., 70:381-390.

Shipboard Scientific Party, 1991a. Geological background and objectives. In Taira, A., Hill, I., Firth, J.V., et al., Proc. ODP, Init. Repts., 131: College Station, TX (Ocean Drilling Program), 5-14.

1991b. Site 808. In Taira, A., Hill, I., Firth, J.V., et al., Proc. ODP, Init. Repts., 131: College Station, TX (Ocean Drilling Program), 71-272.

Srodon, J., 1980. Precise identification of illite/smectite interstratifications by X-ray powder diffraction. Clays Clay Miner., 28:401-411.

, 1981. X-ray identification of randomly interstratified illite-smectite in mixtures with discrete illite. Clay Miner., 16:297-304.

, 1984. X-ray powder diffraction identification of illitic materials. Clays Clay Miner, 32:337-349.

Starkey, H.C., Blackmon, P.D., and Hauff, P.C., 1984. The routine mineralogical analysis of clay bearing samples. U.S. Geol. Surv. Bull., 1563:1-32.
Sugisaki, R., 1980. Major-element chemistry of argillaceous sediments at Deep Sea Drilling Project Sites 442, 443, and 444, Shikoku Basin. In Klein, G.deV., Kobayashi, K., et al., Init. Repts. DSDP, 58: Washington (U.S Govt. Printing Office), 719-735.

Taira, A., Hill, I., Firth, J., Berner, U., Brückmann, W., Byrne, T., Chabernaud, T., Fisher, A., Foucher, J.-P., Gamo, T., Gieskes, J., Hyndman, R., Karig, D., Kastner, M., Kato, Y., Lallement, S., Lu, R., Maltman, A., Moore, G., Moran, K., Olaffson, G., Owens, W., Pickering, K., Siena, F., Taylor, E., Underwood, M., Wilkinson, C., Yamano, M., and Zhang, J., 1992. Sediment deformation and hydrogeology of the Nankai accretionary prism: synthesis of shipboard results of ODP Leg 131. Earth Planet. Sci. Lett., 109:431-450.

Taira, A., and Niitsuma, N., 1986. Turbidite sedimentation in the Nankai Trough as interpreted from magnetic fabric, grain size, and detrital modal analyses. In Kagami, H., Karig, D.E., Coulbourn, W.T., et al., Init. Repts. DSDP, 87: Washington (U.S. Govt. Printing Office), 611-632.

Terakado, Y., Shimizu, H., and Masuda, A., 1988. Nd and Sr isotopic variations in acidic rocks formed under a peculiar tectonic environment in Miocene Southwest Japan. Contrib. Mineral. Petrol., 99:1-10.

Tomita, K., Takahashi, H., and Watanabe, T., 1988. Quantification curves for mica/smectite interstratifications by X-ray powder diffraction. Clays Clay Miner., 36:258-262.

Tribble, J.S., 1990. Clay diagenesis in the Barbados Accretionary Complex: potential impact on hydrology and subduction dynamics. In Moore, J.C. Mascle, A., et al.,Proc. ODP, Sci. Results, 110: College Station, TX (Ocean Drilling Program), 97-110.

Veblen, D.R., Guthrie, G.D., Jr., and Livi, K.J.T., 1990. High-resolution transmission electron microscopy and electron diffraction of mixed-layer illite/smectite: experimental results. Clays Clay Miner, 38:1-13.

Velde, B., and Espitalie, J., 1989. Comparison of kerogen maturation and illite/smectite composition in diagenesis. J. Pet. Geol., 12:103-110.

Velde, B., and lijima, A., 1988. Comparison of clay and zeolite mineral occurrences in Neogene age sediments from several deep wells. Clays Clay Miner., 36:337-342.

Velde, B., Suzuki, T., and Nicot, E., 1986. Pressure-temperature-composition of illite/smectite mixed-layer minerals: Niger Delta mudstones and other examples. Clays Clay Miner., 34:435-441.

von Huene, R., 1974. Modern trench sediments. In Burk, C.A., and Drake, C.L. (Eds.), The Geology of Continental Margins: New York (SpringerVerlag), 207-212.

Vrolijk, P., 1990. On the mechanical role of smectite in subduction zones. Geology, 18:703-707.

Vrolijk, P., Fisher, A., and Gieskes, J., 1991. Geochemical and geothermal evidence for fluid migration in the Barbados accretionary prism (ODP Leg 110). Geophys. Res. Lett., 18:947-950.

Walker, J.R., and Thompson, G.R., 1990. Structural variations in chlorite and illite in a diagenetic sequence from the Imperial Valley, California. Clays Clay Miner., 38:315-321.

Wang, Y.-C., Gieskes, J.M., and Musoke, L., 1990. Bulk chemical analysis of sediments-Hole 671B. In Moore, J.C., Mascle, A., et al., Proc. ODP, Sci. Results, 110: College Station, TX (Ocean Drilling Program), 179-188.

Watanabe, T., 1988. The structural model of illite/smectite interstratified mineral and the diagram for its identification. Clay Sci., 7:97-114.

Whitney, G., 1990. Role of water in the smectite-to-illite reaction. Clays Clay Miner., 38:343-350.

Yamano, M., Foucher, J.-P., Kinoshita, M., Fisher, A., Hyndman, R.D., and ODP Leg 131 Shipboard Scientific Party, 1992. Heat flow and fluid flow regime in the western Nankai accretionary prism. Earth Planet. Sci. Lett., 109:451-462.

Yamano, M., Honda, S., and Uyeda, S., 1984. Nankai Trough: a hot trench? Mar. Geophys. Res., 6:187-203.

Yamano, M., Uyeda, S., Aoki, Y., and Shipley, T.H., 1982. Estimates of heat flow derived from gas hydrates. Geology, 10:339-343.

Yau, Y.-C., Peacor, D.R., and McDowell, S.D., 1987. Smectite-to-illite reactions in Salton Sea shales: a transmission and analytical electron microscopy study. J. Sediment. Petrol., 57:335-342.

Date of initial receipt: 29 April 1992

Date of acceptance: 22 October 1992

Ms 131SR-137 